\title{
Identified a Disintegrin and Metalloproteinase with Thrombospondin Motifs 6 Serve as a Novel Gastric Cancer Prognostic Biomarker by Integrating Analysis of Gene Expression Profile
}

\author{
Ya-zhen Zhu \\ GuangXi University of Chinese Medicine https://orcid.org/0000-0001-6932-698X \\ Yi Liu \\ Guangxi Cancer Hospital and Guangxi Medical University Affiliated Cancer Hospital \\ Xi-wen Liao \\ Guangxi Cancer Hospital and Guangxi Medical University Affiliated Cancer Hospital \\ Xian-wei Mo \\ Guangxi Cancer Hospital and Guangxi Medical University Affiliated Cancer Hospital \\ Yuan Lin \\ Guangxi Cancer Hospital and Guangxi Medical University Affiliated Cancer Hospital \\ Wei-zhong Tang \\ Guangxi Cancer Hospital and Guangxi Medical University Affiliated Cancer Hospital \\ Shan-shan Luo ( $\square$ luoshanshan@gxmu.edu.cn )
}

Research article

Keywords: ADAMTS, mRNA, gastric cancer, prognosis

Posted Date: July 14th, 2020

DOI: https://doi.org/10.21203/rs.3.rs-41038/v1

License: (c) (1) This work is licensed under a Creative Commons Attribution 4.0 International License. Read Full License 


\section{Abstract}

Objective: We aimed to explore the prognostic value of a disintegrin and metalloproteinase with thrombospondin motifs (ADAMTS) genes in gastric cancer (GC).

Methods: The RNA-sequencing (RNA-seq) expression data for $351 \mathrm{GC}$ patients and other relevant clinical data was acquired from The Cancer Genome Atlas (TCGA). Survival analysis and a genome-wide gene set enrichment analysis (GSEA) were performed to define the underlying molecular value of the ADAMTS genes in GC development.

Results: The Log rank test with both Cox regression and Kaplan-Meier survival analysis showed that ADAMTS6 expression profile correlated with the GC patients' clinical outcome. Patients with a high expression of ADAMTS6 were associated with poor overall survival (OS). Comprehensive survival analysis of the ADAMTS genes suggests that ADAMTS6 might be an independent predictive factor for the OS in patients with GC. Besides, GSEA demonstrated that ADAMTS6 might be involved in multiple biological processes and pathways, such as the vascular endothelial growth factor A (VEGFA), kirsten rat sarcoma viral oncogene (KRAS), tumor protein P53, c-Jun N-terminal kinase (JNK), cadherin (CDH1) or tumor necrosis factor (TNF) pathways.

Conclusions: In summary, our study demonstrated that ADAMTS6 gene could be used as a potential molecular marker for GC prognosis.

\section{Introduction}

Gastric cancer (GC) is the fourth most common cancer and the second cause of mortality worldwide [1]. The median survival time of patients with GC recurrence and metastasis is less than 1 year [2, 3]. According to the 2015 data at the national cancer center, there were about 679,000 new stomach cancer cases and 498,000 deaths [4]. China accounts for 430,000 new GC cases and 300,000 deaths every year [5]. The GC development may be a process of long-term synergistic action of multiple factors. GC might be triggered by pathogenic infections, such as Helicobacter Pylori (HP) [6-9], or gastric ulcers [10], chronic atrophic gastritis [11], carcinogens such as nitrite in food [12], smoking [13, 14], and long-term drinking [15]. Despite the immense progress made in the clinical management of GC, the prognosis and survival rates of patients remain poor. Low early diagnosis rate and high local recurrence cases coupled with distant metastasis rates for advanced GC results in the poor GC prognosis in China. It is, therefore, vital to further interrogate the carcinogenesis and development of GC in order to develop new prognostic molecular markers and targeted therapy.

A disintegrin and metalloproteinase with thrombospondin motifs (ADAMTS) genes are zinc-dependent metalloproteases. Previous research has demonstrated a close association between ADAMTS and tumor invasion and metastasis [16]. ADAMTS participate in multiple biological pathways, including histomorphogenesis, pathophysiological reconstruction, inflammation, angiogenesis, or tumorigenesis $[17,18]$. However, the diagnostic, prognostic or therapeutic value of the ADAMTS genes in the development of GC is yet to be defined. Here, using The Cancer Genome Atlas (TCGA) and the Kaplan-Meier plotter (KM plotter) tools, we explored the diagnostic and underlying prognostic value of the ADAMTS family of genes in stomach cancer.

\section{Methods}

\section{Public database source}

The RNA-seq expression data for 383 patients and relevant clinical data was acquired from the TCGA database (https://portal.gdc.cancer.gov/; accessed May 15, 2019). The mined data comprised of $351 \mathrm{GC}$ tumors and 32 normal gastric samples. The raw data were normalized via the DESeq (https://www.bioconductor.org/packages/release/bioc/html/DESeq.html) [19].

\section{Bioinformatics analysis}

We used GraphPad Prism 8 to draw the scatter diagram and receiver operating characteristic (ROC) curves of the expression distribution for both the GC and the normal samples. The unpaired t-test was used to compare the differences shown in the 
scatter diagram and the area under ROC curve. Using the Database for Annotation, Visualization and Integrated Discovery (DAVID, (https://david.ncifcrf.gov/home.jsp; accessed December.1, 2019; v.6.8), we then investigated the Gene Ontology (GO) enrichment of ADAMTS genes [20]. We used the gene multiple association network integration algorithm (Gene MANIA; http://www.genemania.org/; accessed December 1, 2019) to construct the gene-gene networks [21, 22] and the Search Tool for the Retrieval of Interacting Genes/Proteins (STRING v.10.0; https://string-db.org/; accessed December 1, 2019) to define the protein-protein interaction (PPI) networks $[23,24]$.

\section{Comprehensive survival analysis of ADAMTS genes}

Using the median values for the gene expression profile, GC patients were classified into two categories based on survival analysis. Both the ADAMTS expression and clinical data in GC tissues or adjacent tissues were analyzed using the log-rank test, while the clinical characteristic related to OS were selected and adjusted by the multivariate Cox regression survival analysis. Besides, the clinical pathological features were further analyzed in the subgroups. We then conducted full survival analysis using the prognostic-related ADAMTS genes, and assessed the survival ROC curves using the $\mathrm{R}$ package platform, as well as the total and subgroup survival analysis. Finally, the prognostic relationship between ADAMTS family of genes and GC was verified by the Kaplan-Meier plotter (KM plotter) database (www.kmplot.com).

\section{GSEA}

We used GSEA (http://software.broadinstitute.org/gsea/index.jsp; accessed December 15, 2020) $[25,26]$ to study the biological differences and pathways affected by the differential expression of the ADAMTS gene pool and their relationship with GC clinical outcome. The GSEA software applies the Molecular Signatures Database (MSigDB) c2 (c2.cp.kegg.v7.0.symbols.gmt) and c5 (c5.all.v7.0.symbols.gmt) [27] in gene set analysis. When a probability value of $P<0.05$ and a false discovery rate (FDR) $<0.25$ for GSEA were considered statistically significant.

\section{Statistical analysis}

We employed the Benjamini-Hochberg program to adjust FDRs in GSEA for multiple tests [28-30]. The statistical analysis was conducted via SPSS version 23.0 (IBM Corporation, Armonk, NY, USA). A probability value of $\mathrm{P}<0.05$ was considered as statistically significant.

\section{Results}

After the expression of ADAMTS mRNA in 351 cases of GC and 32 cases of adjacent tissues by function Log2, the results of unpaired t-test showed that $A D A M T S 1$ and $A D A M T S 8$ mRNA expression was down-regulated in $\mathrm{GC}$ tumor tissues as compared to the adjacent normal tissues $(P<0.05)$. On the other side, ADAMTS2, ADAMTS6 and ADAMTS7 genes were up-regulated in GC tissues $(P<0.05)$, as shown in Figure 1. The AUC and ROC curves for the GC and adjacent normal samples showed that the tumor tissues could be effectively identified based on the risk score (Figure 2).

\section{Bioinformatics analysis}

The GO analysis indicated that the ADAMTS genes was linked with extracellular matrix/structure organization, extracellular matrix disassembly, cell adhesion molecule binding, or collagen catabolic/metabolic processes, as shown in Figure 3. Our interaction network analysis showed that ADAMTS genes and other related genes formed an intricate network together. The genegene interaction network showed that the ADAMTS genes are strongly co-expressed (Figure 4A), while the PPI network analysis showed that the ADAMTS proteins directly interact with each other (Figure 4B). Furthermore, there was co-expression among the ADAMTS1-8 genes in the GC tumor tissues (Figure 5), demonstrating that the genes are positively correlated with GC development (Pearson correlation coefficient ranged 0.11-0.69; $P<0.05$ ). Besides, our analysis of the ADAMTS genes expression in different tumor stages and histologic grades showed that the ADAMTS6 expression was significantly different in G1/G2 and G3 tumor tissues (Figure 6A). However, there was no significant difference in the expression of ADAMTS genes in stage $\mathrm{I} / \mathrm{II}$ and III/IV tumor samples (Figure 6B). Together, this data shows that ADAMTS6 overexpression is associated with G3 tumor tissues samples in GC patients, $p=0.01$ (Figure 6A). 
The clinical characteristics of the $351 \mathrm{GC}$ patients is shown in table 1. The results from the univariate analysis found that the high ADAMTS1 and ADAMTS6 mRNA expression was associated with poor survival rates of $\mathrm{GC}$ patients $(\mathrm{HR}=1.52,95 \% \mathrm{Cl}=1.09-$ 2.12, $\mathrm{P}=0.013$ and $\mathrm{HR}=1.80,95 \% \mathrm{Cl}=1.29-2.51, \mathrm{P}=0.001$, respectively) as shown in table 2. Unlike the other ADAMTS genes, the survival analysis indicated that the up-regulation of ADAMTS1, ADAMTS3, or ADAMTS6 increased the death rate in GC patients $(P<0.05)$ (Figure 7A-H). Clinical parameters such as age, TNM stage, cancer status, primary therapy outcome, residual tumor, and therapy were remarkably correlated with OS in GC. Indeed, the adjusted multivariate Cox regression indicated that the overexpression of the ADAMTS6 protein was associated with increased death rates in GC patients (adjusted HR=1.89, $95 \%$ $\mathrm{Cl}=1.19-3.01$, adjusted $\mathrm{P}=0.007$, Table 2, Figure 7F). The up-regulated expression of ADAMTS6 gene reduced the GC OS by more than half (high ADAMTS6 vs low ADAMTS6; 21 months vs 56 months) as shown in Table 2, Figure 7F and Figure8A. There was, however, no correlation between other ADAMTS genes and the GC OS. In addition, as shown in Table 3, subgroup analysis indicated that overexpression of the ADAMTS6 genes increased the death rate in GC patients who are $\geq 60$ years old; female patients; patients with gastric antrum cancer; intestinal type adenocarcinoma; G2, G3 histologic grade; MSI-H, MMS; lymph node metastasis; T3, T4; tumor free status; pathologic stage III; R0 resection; those untreated with radiation therapy or targeted therapy, without distant metastasis and HP infection. Time-dependent ROC analysis proved that ADAMTS6 expression profile could reliably predict OS in GC patients. The area under the 1-year, 2-year or 3-year curve (AUC) was $0.613,0.607$ or 0.759 , respectively (Figure 8B). Besides, we demonstrate that ADAMTS6, together with the OS-related clinical characteristics give superior performance in the prediction OS in GC patients (Figure 9A-E and Table 4).

\section{K-M plotter survival analysis}

The expression profile for the ADAMTS genes in the K-M plotter database demonstrated that patients with high expression had poor clinical outcomes (Figure 10 and Table 5). The data from the Lauren classification of the ADAMTS mRNA expression of the GC patients showed that the patients with high expression of diffuse ADAMTS5 (Affymetrix ID: 235368_at) gene, intestinal ADAMTS1 (Affymetrix ID: 222486_s_at), ADAMTS2 (Affymetrix ID: 226311_at), ADAMTS3 (Affymetrix ID: 214913_at), ADAMTS4 (Affymetrix ID: 214913_at), ADAMTS6 (Affymetrix ID: 237411_at) or ADAMTS7 (Affymetrix ID: 228911_at) had shorter survival time compared to those with low expression (Figure 11, Figure 12 and Table 6). Table 7-10 shows the stratified results of the ADAMTS expression in TNM stage, tumor differentiation degree, different treatment strategies and HER2 status of the GC cases. The high expression of ADAMTS1 in tumor stage IV (adjusted $P=0.036$, adjusted $\mathrm{HR}=1.52,95 \% \mathrm{Cl}=1.02-2.27$ ), ADAMTS2 in stage III (adjusted $P=0.02$, adjusted $\mathrm{HR}=1.56,95 \% \mathrm{Cl}=1.07-2.28$ ), ADAMTS5 in stage III and stage IV (adjusted $\mathrm{P}=0.002$, adjusted $\mathrm{HR}=1.81,95 \% \mathrm{Cl}=1.24-2.64$ and adjusted $P=0.04$, adjusted $\mathrm{HR}=1.51,95 \% \mathrm{Cl}=1.02-2.25)$, ADAMTS7 in stage III and stage IV (adjusted $P=0.0026$, adjusted $\mathrm{HR}=1.77,95 \% \mathrm{Cl}=1.21-2.57$ and adjusted $P=0.0047$, adjusted $\mathrm{HR}=1.76,95 \% \mathrm{Cl}=1.18-$ 2.63 ) increased the mortality rate, while a high expression of $A D A M T S 2$ in tumor stage I (adjusted $P=0.03$, adjusted $\mathrm{HR}=0.26$, $95 \% \mathrm{Cl}=0.07-0.96)$ increased the survival rate in GC patients. Similarly, the high expression in $\mathrm{G} 2$ degree of tumor differentiation of $A D A M T S 7$ (adjusted $P=0.0074$, adjusted $\mathrm{HR}=2.39,95 \% \mathrm{Cl}=1.24-4.59$ ) increased the death rate in $\mathrm{GC}$ patients. In addition, the mortality rate in patients with high expression of ADAMTS genes after surgery was higher than those with low expression. The HER2 state subgroup analysis showed that the high expression of ADAMTS family of genes increased mortality in patients with HER2 positive and HER2 negative status, but not in ADAMTS5, ADAMTS7 HER2 positive patients.

\section{GSEA}

The GSEA data indicated that, in the $\mathrm{c} 2$ category, the high expression of ADAMTS6 may participate in extracellular matrix organization, development of advanced GC, metastasis, ECM receptor interaction, vascular endothelial growth factor A (VEGFA), kirsten rat sarcoma viral oncogene (KRAS), c-Jun N-terminal kinase (JNK) and cadherin (CDH1) signaling pathways (Figure 13AI). In the c5 category, down-regulation of the ADAMTS6 expression might be linked with DNA damage, cell cycle, apoptosis, glycolysis, fatty acid metabolism, mRNA catabolism, tumor protein p53 and tumor necrosis factor (TNF) signaling pathways (Figure 14A-I).

\section{Discussions}


Invasive growth and distant metastasis are the two most key features that characterize malignancy, which are also the primary reason for high mortality. Rapid proliferation and metastasis of tumors is facilitated by emergence of new blood vessels in the stroma [31]. Thus, inhibiting angiogenesis may be an effective strategy to inhibit cancer growth. The most significant feature of the ADAMTS family of enzymes is there diversity in thrombospondin type 1 (TSP1) motifs at the C-terminus. The TSP1 motifs are highly conserved and are an endogenous inhibitor of angiogenesis. It inhibits endothelial cell proliferation, induce endothelial cell apoptosis and anti-angiogenesis through its interaction with CD36 receptor [32].

In our study, GO enrichment analysis revealed that $A D A M T S$ gene family is related to extracellular matrix/structure organization, extracellular matrix disassembly, and binding of cell adhesion molecules. Cell adhesion molecules mediate the interaction between cells or between the cells and matrix [33]. These adhesion molecules are synthesized and secreted by a variety of cells, and participate in the occurrence and metastasis of tumors [34]. In preventing tumor metastasis, extracellular matrix organization play an important regulatory roles and its dissolution can promote tumor growth and metastasis. Previous data has suggested that the ADAMTS family of genes play a vital role in the degradation of extracellular matrix [35]. Thus, the ADAMTS genes might be key anti-invasive molecules. The co-expression of the ADAMTS1-8 genes show positive correlation with GC tumors. Nevertheless, data on the molecular expression and the role of ADAMTS set of genes in GC are still scants.

Several studies have revealed that ADAMTS1 is down-regulated in a variety of tumors [36-38], as well as in GC tumor tissue ${ }^{\text {[39] }}$. In our study, there was low expression of ADAMTS1 mRNA in GC tissues compared to those in adjacent tissues, $\mathrm{p}<0.001$. Besides, the survival analysis also demonstrated that up-regulation of the ADAMTS1 is associated with poor survival time in GC patients $(P=0.013)$, but not in multi factor analysis $(p>0.05)$. Whereas the ADAMTS1 gene expression level correlates with OS in stomach cancer patients, it is not an independent prognostic biomarker for $\mathrm{GC}$, thus more validation studies are required.

Compared with the normal tissues, ADAMTS2 expression in GC tumor cells and fibroblasts was significantly increased, and the up-regulation of the ADAMTS2 was associated with poor prognosis of GC patients [40]. Our data demonstrated that the expression of ADAMTS2 increases in $\mathrm{GC}, \mathrm{p}<0.001$, but the high expression did not affect mortality in $\mathrm{GC}(\mathrm{p}>0.05)$.

It has also been observed that the increased expression of ADAMTS3 gene taking a major part in the development of myocardial infarction, osteoarthritis, and breast cancer ${ }^{[41]}$. Our study found the expression level of ADAMTS3 gene is not associated with the GC OS. Whereas ADAMTS4 expression was significantly up-regulated in invasive breast cancer tissues [42] and human glioma [43], our study showed that the expression of ADAMTS4 gene does not affect the OS of GC patients. Similarly, unlike previous studies [44-47], our findings shows that the expression profile of ADAMTS5 gene does not correlate with survival of GC patients. In addition, $A D A M T S 7$ is involved in the migration and proliferation of smooth muscle and the development of atherosclerosis and restenosis ${ }^{[48]}$. Our current findings indicates the expression level of the ADAMTS7 gene is not related to OS in GC patients. Previous studies have shown that the ADAMTS8 expression is down-regulated in breast cancer, brain cancer and non-small cell lung cancer [49-51]. Whereas our data showed down-regulation of the ADAMTS8 mRNA expression in GC, $p<0.001$, the low expression was not correlated with the risk of GC-specific mortality $(p>0.05)$.

The up-regulation of ADAMTS6 is a molecular marker for poor prognosis in esophageal squamous cell carcinoma [52]. Besides, some researches have demonstrated that ADAMTS6 is dysregulated in breast cancer [53], prolactin tumors [54] and colorectal cancer [55]. In this study, we revealed that ADAMTS6 mRNA is overexpressed in GC tissues, $\mathrm{p}<0.001$. ADAMTS6 expression is largely correlated with tumor stage, targeted molecular therapy, radical resection, radiation therapy and histological grade of the GC. Our analysis indicated that the high expression of ADAMTS6 was an independent predictive factor for GC in TCGA database. Stratified analysis of the clinic pathological parameters such as age, gender and TNM stage also showed that patients with the high expression of ADAMTS6 have reduced survival than those with low expression. Similarly, the multivariate survival and stratified analysis showed that the ADAMTS6 mRNA was up-regulated in GC patients and led to poor survival time. In addition, the ADAMTS6 gene was shown to promote the occurrence and development of stomach cancer. Our study revealed that ADAMTS6 is a tumor promoter, whose overexpression mediates occurrence, proliferation, invasion, or metastasis of stomach tumor, thus leading to a high mortality. Therefore, the ADAMTS6 gene may be a potential therapeutic target for GC.

The GSEA analysis indicated that ADAMTS6 enriched cancer-related pathways, such as apoptosis, VEGF, KRAS, P53, JNK, CDH1, or TNF pathways, which may affect GC prognosis. Apoptosis plays a significant role in maintaining the stability of the internal 
environment. The balance between cell proliferation and apoptosis is pivotal to the stability of human internal environment, otherwise, any perturbation of this state might lead to tumorigenesis [56]. VEGF mediates angiogenesis, which has been considered as the strongest cytokine promoting tumor angiogenesis [57]. It has been shown that inhibition of the VEGF signaling pathway inhibits neovascularization, thus blocking the occurrence and metastasis of tumors [58]. KRAS is the most common mutation type in the RAS family of genes that affects the development of tumors $[59,60]$. Once KRAS mutates, it will lose the activity of GTP hydrolase, and thus continue to activate, promoting the uncontrolled cell proliferation and carcinogenesis. Besides, mutations in the p53 gene renders it ineffective in regulating cell growth, apoptosis, DNA repair and so on, causing cell transformation and cancer [61, 62]. Deveci et al demonstrated that the P53 gene is associated with the occurrence and development of GC [63]. JNK signaling pathway plays a significant part in regulation of cell cycle, reproduction, apoptosis and cell stress. Moreover, Yan et al., emphasized that inhibition of JNK signaling pathway may lead to apoptosis and metastasis of GC $[64,65]$. CDH1 gene mutation is a marker for poor GC prognosis [66-69]. TNF is involved in the inflammation and cellular immune response as well as tumor regulatory mechanisms [70-7270-72]. The findings infer that ADAMTS6 may be involved in cancer-related pathways, including VEGF, KRAS, P53, JNK, CDH1 or TNF pathways, which play a crucial role in GC prognosis.

Our study has several limitations. Our study dependent on data from a public database, thus the ADAMTS and survival analysis findings require further validation. Therefore, further experiment verification of the expression and function of ADAMTS is very necessary to improve the credibility of our current study. Besides, the underlying molecular mechanisms by which ADAMTS6 affects the occurrence and prognosis of GC needs further interrogation. In addition, because the information on TCGA database is incomplete, we were unable to clearly evaluate the relationship between the mRNA expression of the ADAMTS family of genes and protein expression. Subsequent studies need to reveal the biological mechanism of ADAMTS6 in the development and metastasis of GC from various aspects.

Despite these limitations, this study is the first to investigate the correlation between ADAMTS mRNA expression and survive time in patients with stomach cancer. Log-rank test with Cox regression survival analysis and Kaplan-Meier survival analysis method were performed and found that ADAMTS6 expression level was largely correlated to GC patient clinical prognosis outcome. Thus, the prognostic relationship between ADAMTS family and GC was verified in the KM plotter database. Finally, GSEA found the differences of biological processes and related tumor pathways. Once these consequences are confirmed, we anticipate that ADAMTS6-targeted therapy drugs will be used in GC patients.

\section{Conclusions}

Our research reveals that the up-regulation of ADAMTS6 is significantly associated with poor prognosis, and might be used as an independent predictive factor for GC. The potential mechanism of ADAMTS6 in GC prognosis was involved in cancer-related biologic processes and pathways, including apoptosis, VEGF, KRAS, P53, JNK, CDH1, or TNF pathways. Nevertheless, the potential mechanism of ADAMTS6 still need further verification and investigation.

\section{Abbreviations}

ADAMTS. A Disintegrin and Metalloproteinase with Thrombospondin motifs; GC: gastric cancer; TCGA: The Cancer Genome Atlas; OS: overall survival; RNA-Seq: RNA-sequencing; KM plotter: Kaplan-Meier plotter; HP: Helicobacter Pylori; DAVID: Database for Annotation, Visualization and Integrated Discovery; MANIA: multiple association network integration algorithm; STRING:

Search Tool for the Retrieval of Interacting Genes/Proteins; GSEA: Gene set enrichment analysis; FDR: false discovery rate; AUC: area under curve; HR: hazard ratio; Cl: confidence interval; GO: Gene Ontology; VEGFA: the vascular endothelial growth factor A; KRAS: kirsten rat sarcoma viral oncogene; JNK: c-Jun N-terminal kinase; TNF: tumor necrosis factor.

\section{Declarations}

\section{Acknowledgements}

The authors thank the contributors of TCGA (https://cancergenome.nih.gov/) and UCSC Xena (http://xena.ucsc.edu/) for sharing the gastric cancer data on open access. 


\section{Conflicts of Interest}

The authors declare that they have no conflicts of interest.

\section{Consent for publication}

Not applicable.

\section{Authors' Contributions}

Ya-Zhen Zhu, Yi Liu, Xi-Wen Liao, Xian-Wei Mo1, Yuan Lin1, Wei-Zhong Tang and Shan-Shan Luo designed this manuscript, conducted the study, collected and analyzed the data. Ya-Zhen Zhu wrote this manuscript; Yi Liu, Xi-Wen Liao, Xian-Wei Mo, Yuan Lin, Wei-Zhong Tang contributed to the data interpretation, and Shan-Shan Luo guided the writing.

\section{Ethics approval and consent to participate}

This study does not contain any experiments using human participants or animals performed by any of the authors. All datasets in our current study were acquired from the TCGA database and used in consistent with publication guidelines and access policy of TCGA (https://cancergenome.nih.gov/ publications/publication guidelines), therefore the study does not require ethics committee approval.

\section{Data Availability}

The data used to support the findings of this study are available from the corresponding author.

\section{Funding}

No funding was received.

\section{References}

1. Jemal A, Center MM, DeSantis C, Ward EM. Global patterns of cancer incidence and mortality rates and trends. Cancer epidemiology, biomarkers \& prevention: a publication of the American Association for Cancer Research, cosponsored by the American Society of Preventive Oncology. 2010; 19: 1893-907.

2. Bray F, Ferlay J, Soerjomataram I, Siegel RL, Torre LA, Jemal A. Global cancer statistics 2018: GLOBOCAN estimates of incidence and mortality worldwide for 36 cancers in 185 countries. Cancer J Clin. 2018;68:394-424.

3. Kim Y, Byeon SJ, Hur J, Lee K, Kim D, Ahn JH, et al. High delta-like ligand 4 expression correlates with a poor clinical outcome in gastric cancer. J Cancer. 2019;10:3172-8.

4. Donaldson PT, Ho S, Williams R, Johnson PJ. HLA class II alleles in Chinese patients with hepatocellular carcinoma. Liver. 2001;21:143-8.

5. Chen WQ, Li H, Sun KX, Zheng RS, Zhang SW, Zeng HM, et al. [Report of Cancer Incidence and Mortality in China, 2014]. Zhonghua zhong liu za zhi [Chinese journal of oncology]. 2018; 40: 5-13.

6. Akgollu E, Bilgin R, Akkiz H, Ulger Y, Kaya BY, Karaogullarindan U, et al. Association between chronic hepatitis B virus infection and HLA-DP gene polymorphisms in the Turkish population. Virus Res. 2017;232:6-12.

7. Gonzalez CA, Megraud F, Buissonniere A, Lujan Barroso L, Agudo A, Duell EJ, et al. Helicobacter pylori infection assessed by ELISA and by immunoblot and noncardia gastric cancer risk in a prospective study: the Eurgast-EPIC project. Annals of oncology: official journal of the European Society for Medical Oncology. 2012;23:1320-4.

8. Lochhead P, El-Omar EM. Helicobacter pylori infection and gastric cancer. Best practice research Clinical gastroenterology. 2007;21:281-97.

9. Plummer M, Franceschi S, Vignat J, Forman D, de Martel C. Global burden of gastric cancer attributable to Helicobacter pylori. International journal of cancer. 2015;136:487-90. 
10. Sogaard KK, Farkas DK, Pedersen L, Lund JL, Thomsen RW, Sorensen HT. Long-term risk of gastrointestinal cancers in persons with gastric or duodenal ulcers. Cancer medicine. 2016;5:1341-51.

11. Yu L, Cheng YJ, Cheng ML, Yao YM, Zhang Q, Zhao XK, et al. Quantitative assessment of common genetic variations in HLADP with hepatitis B virus infection, clearance and hepatocellular carcinoma development. Scientific reports. 2015;5:14933.

12. Tricker AR, Preussmann R. Carcinogenic N-nitrosamines in the diet: occurrence, formation, mechanisms and carcinogenic potential. Mutat Res. 1991;259:277-89.

13. Freedman ND, Abnet CC, Leitzmann MF, Mouw T, Subar AF, Hollenbeck AR, et al. A prospective study of tobacco, alcohol, and the risk of esophageal and gastric cancer subtypes. Am J Epidemiol. 2007;165:1424-33.

14. Steevens J, Schouten LJ, Goldbohm RA, van den Brandt PA. Alcohol consumption, cigarette smoking and risk of subtypes of oesophageal and gastric cancer: a prospective cohort study. Gut. 2010;59:39-48.

15. Dong J, Thrift AP. Alcohol, smoking and risk of oesophago-gastric cancer. Best practice research Clinical gastroenterology. 2017;31:509-17.

16. Rocks N, Paulissen G, El Hour M, Quesada F, Crahay C, Gueders M, et al. Emerging roles of ADAM and ADAMTS metalloproteinases in cancer. Biochimie. 2008;90:369-79.

17. Porter S, Clark IM, Kevorkian L, Edwards DR. The ADAMTS metalloproteinases. Biochem J. 2005;386:15-27.

18. Kelwick R, Desanlis I, Wheeler GN, Edwards DR. The ADAMTS (A Disintegrin and Metalloproteinase with Thrombospondin motifs) family. Genome biology. 2015;16:113.

19. Anders S, Huber W. Differential expression analysis for sequence count data. Genome Biol. 2010;11:R106.

20. Dennis G Jr, Sherman BT, Hosack DA, Yang J, Gao W, Lane HC, et al. DAVID: Database for Annotation, Visualization, and Integrated Discovery. Genome biology. 2003;4:P3.

21. Mostafavi S, Ray D, Warde-Farley D, Grouios C, Morris Q. GeneMANIA: a real-time multiple association network integration algorithm for predicting gene function. Genome biology. 2008;9(Suppl 1):4.

22. Warde-Farley D, Donaldson SL, Comes O, Zuberi K, Badrawi R, Chao P, et al. The GeneMANIA prediction server: biological network integration for gene prioritization and predicting gene function. Nucleic acids research. 2010;38:W214-20.

23. von Mering C, Huynen M, Jaeggi D, Schmidt S, Bork P, Snel B. STRING: a database of predicted functional associations between proteins. Nucleic acids research. 2003;31:258-61.

24. von Mering C, Jensen LJ, Snel B, Hooper SD, Krupp M, Foglierini M, et al. STRING: known and predicted protein-protein associations, integrated and transferred across organisms. Nucleic acids research. 2005;33:D433-7.

25. Mootha VK, Lindgren CM, Eriksson K-F, Subramanian A 1, Lehar SS, Puigserver J. P, et al. PGC-1a-responsive genes involved in oxidative phosphorylation are coordinately downregulated in human diabetes. Nat Genet. 2003;34:267-73.

26. Subramanian A, Tamayo P, Mootha VK, Mukherjee S, Ebert BL, Gillette MA, et al. Gene set enrichment analysis: A knowledgebased approach for interpreting genome-wide expression profiles. The National Academy of Sciences of the USA. 2005;102:15545-50.

27. Liberzon A, Birger C, Thorvaldsdóttir H, Ghandi M, Mesirov Jill P, Tamayo P. The Molecular Signatures Database Hallmark Gene Set Collection. Cell Systems. 2015;1:417-25.

28. Benjamini Y, Drai D, Elmer G, Kafkafı N, Golani I. Controlling the false discovery rate in behavior genetics research. Behav Brain Res. 2001;125:279-84.

29. Reiner A, Yekutieli D, Benjamini Y. Identifying differentially expressed genes using false discovery rate controlling procedures. Bioinformatics. 2003;19:368-75.

30. Y B, Y H. Controlling the false discovery rate: a practical and powerful approach to multiple testing. J Royal Stat Soc. 1995; 57: $289-300$.

31. Hanahan D, Folkman J. Patterns and emerging mechanisms of the angiogenic switch during tumorigenesis. Cell. 1996;86:353-64.

32. Gantus MA, Nasciutti LE, Cruz CM, Persechini PM, Martinez AM. Modulation of extracellular matrix components by metalloproteinases and their tissue inhibitors during degeneration and regeneration of rat sural nerve. Brain research. 
2006;1122:36-46.

33. Freitas VM, do Amaral JB, Silva TA, Santos ES, Mangone FR, Pinheiro Jde J, et al. Decreased expression of ADAMTS-1 in human breast tumors stimulates migration and invasion. Mol Cancer. 2013;12:2.

34. Wagstaff L, Kelwick R, Decock J, Edwards DR. The roles of ADAMTS metalloproteinases in tumorigenesis and metastasis. Frontiers in bioscience. 2011;16:1861-72.

35. van Goor H, Melenhorst WB, Turner AJ, Holgate ST. Adamalysins in biology and disease. J Pathol. 2009;219:277-86.

36. Choi JE, Kim DS, Kim EJ, Chae MH, Cha SI, Kim CH, et al. Aberrant methylation of ADAMTS1 in non-small cell lung cancer. Cancer Genet Cytogenet. 2008;187:80-4.

37. Gustavsson H, Wang W, Jennbacken K, Welén K, Damber J-E. ADAMTS1, a putative anti-angiogenic factor, is decreased in human prostate cancer. BJU Int. 2009;104:1786-90.

38. Masui T, Tuji S, Ida J, Nakajima S, Kawaguch M, Koizumi M. Expression of METH-1 and METH-2 in Pancreatic Cancer. Clin Cancer Res. 2001;7:3437-43.

39. Lind GE, Kleivi K, Meling GI, Teixeira MR, Thiis-Evensen E, Rognum TO, et al. ADAMTS1, CRABP1, a n d NR3C1 identified as epigenetically deregulated genes in colorectal tumorigenesis. Cell Oncol. 2006;28:259-72.

40. Jiang $C$, Zhou $Y$, Huang $Y$, Wang $Y$, Wang W, Kuai X. Overexpression of ADAMTS-2 in tumor cells and stroma is predictive of poor clinical prognosis in gastric cancer. Human pathology. 2019;84:44-51.

41. Alper M, Aydemir AT, Kockar F. Induction of human ADAMTS-2 gene expression by IL-1alpha is mediated by a multiple crosstalk of MEK/JNK and PI3K pathways in osteoblast like cells. Gene. 2015;573:321-7.

42. Kelwick R, Desanlis I, Wheeler GN, Edwards DR. The ADAMTS (A Disintegrin and Metalloproteinase with Thrombospondin motifs) family. Genome Biology. 2015; 16.

43. Held-Feindt J, Paredes EB, Blömer U, Seidenbecher C, Stark AM, Mehdorn HM, et al. Matrix-degrading proteases ADAMTS4 and ADAMTS5 (disintegrins and metalloproteinases with thrombospondin motifs 4 and 5) are expressed in human glioblastomas. Int J Cancer. 2006;118:55-61.

44. Gu J, Chen J, Feng J, Liu Y, Xue Q, Mao G, et al. Overexpression of ADAMTS5 can regulate the migration and invasion of non-small cell lung cancer. Tumour biology: the journal of the International Society for Oncodevelopmental Biology Medicine. 2016;37:8681-9.

45. Li C, Xiong Y, Yang X, Wang L, Zhang S, Dai N, et al. Lost expression of ADAMTS5 protein associates with progression and poor prognosis of hepatocellular carcinoma. Drug Des Devel Ther. 2015;9:1773-83.

46. Li J, Liao Y, Huang J, Sun Y, Chen $\mathrm{H}$, Chen $\mathrm{C}$, et al. Epigenetic silencing of ADAMTS5 is associated with increased invasiveness and poor survival in patients with colorectal cancer. J Cancer Res Clin Oncol. 2018;144:215-27.

47. Nakada M, Miyamori H, Kita D, Takahashi T, Yamashita J, Sato H, et al. Human glioblastomas overexpress ADAMTS-5 that degrades brevican. Acta Neuropathol. 2005;110:239-46.

48. Pu X, Xiao Q, Kiechl S, Chan K, Ng FL, Gor S, et al. ADAMTS7 cleavage and vascular smooth muscle cell migration is affected by a coronary-artery-disease-associated variant. Am J Hum Genet. 2013;92:366-74.

49. Choi GC, Li J, Wang Y, Li L, Zhong L, Ma B, et al. The metalloprotease ADAMTS8 displays antitumor properties through antagonizing EGFR-MEK-ERK signaling and is silenced in carcinomas by CpG methylation. Molecular cancer research: MCR. 2014;12:228-38.

50. Dunn JR, Panutsopulos D, Shaw MW, Heighway J, Dormer R, Salmo EN, et al. METH-2 silencing and promoter hypermethylation in NSCLC. British journal of cancer. 2004;91:1149-54.

51. Koo BH, Coe DM, Dixon LJ, Somerville RP, Nelson CM, Wang LW, et al. ADAMTS9 is a cell-autonomously acting, antiangiogenic metalloprotease expressed by microvascular endothelial cells. Am J Pathol. 2010;176:1494-504.

52. Liu L, Yang Z, Ni W, Xuan Y. ADAMTS- 6 is a predictor of poor prognosis in patients with esophageal squamous cell carcinoma. Exp Mol Pathol. 2018;104:134-9.

53. Porter S, Scott SD, Sassoon EM, Williams MR, Jones JL, Girling AC, et al. Dysregulated expression of adamalysinthrombospondin genes in human breast carcinoma. Clinical cancer research: an official journal of the American Association 
for Cancer Research. 2004;10:2429-40.

54. Wierinckx A, Auger C, Devauchelle P, Reynaud A, Chevallier P, Jan M, et al. A diagnostic marker set for invasion, proliferation, and aggressiveness of prolactin pituitary tumors. Endocrine-related Cancer. 2007;14:887-900.

55. Xiao WH, Qu XL, Li XM, Sun YL, Zhao HX, Wang S, et al. Identification of commonly dysregulated genes in colorectal cancer by integrating analysis of RNA-Seq data and qRT-PCR validation. Cancer Gene Ther. 2015;22:278-84.

56. Espinosa M, Cantu D, Herrera N, Lopez CM, De la Garza JG, Maldonado V, et al. Inhibitors of apoptosis proteins in human cervical cancer. BMC Cancer. 2006;6:45.

57. Fan X, Krieg S, Kuo CJ, Wiegand SJ, Rabinovitch M, Druzin ML, et al. VEGF blockade inhibits angiogenesis and reepithelialization of endometrium. FASEB journal: official publication of the Federation of American Societies for Experimental Biology. 2008;22:3571-80.

58. Hui-Zhuo X, Shuang-Zhen L, Si-Qi X, Xiao-Bo X. HIF-1 a siRNA reduces retinal neovascularization in a mouse model of retinopathy of prematurity. Chin J Contemp Pediatr. 2011;13:680-3.

59. Albertini AF, Raoux D, Neumann F, Rossat S, Tabet F, Pedeutour F, et al. [Detection of RAS genes mutation using the Cobas $((\mathrm{R}))$ method in a private laboratory of pathology: Medical and economical study in comparison to a public platform of molecular biology of cancer]. Bulletin du cancer. 2017;104:662-74.

60. Liu ZM, Liu LN, Li M, Zhang QP, Cheng SH, Lu S. Mutation detection of KRAS by high-resolution melting analysis in Chinese with gastric cancer. Oncol Rep. 2009;22:515-20.

61. Chari NS, Pinaire NL, Thorpe L, Medeiros LJ, Routbort MJ, McDonnell TJ. The p53 tumor suppressor network in cancer and the therapeutic modulation of cell death. Apoptosis: an international journal on programmed cell death. 2009;14:336-47.

62. Machado-Silva A, Perrier S, Bourdon JC. p53 family members in cancer diagnosis and treatment. Sem Cancer Biol. 2010;20:57-62.

63. Deveci MS, Deveci G. Prognostic value of p53 protein and MK-1 (a tumor-associated antigen) expression in gastric carcinoma. Gastric cancer: official journal of the International Gastric Cancer Association the Japanese Gastric Cancer Association. 2007;10:112-6.

64. Choi Y, Ko YS, Park J, Choi Y, Kim Y, Pyo JS, et al. HER2-induced metastasis is mediated by AKT/JNK/EMT signaling pathway in gastric cancer. World journal of gastroenterology. 2016;22:9141-53.

65. Yan H, Xiao F, Zou J, Qiu C, Sun W, Gu M, et al. NR4A1-induced increase in the sensitivity of a human gastric cancer line to TNFalpha-mediated apoptosis is associated with the inhibition of JNK/Parkin-dependent mitophagy. Int $\mathrm{J}$ Oncol. 2018;52:367-78.

66. Cho J, Ahn S, Son DS, Kim NK, Lee KW, Kim S, et al. Bridging genomics and phenomics of gastric carcinoma. Int J Cancer. 2019;145:2407-17.

67. Cho SY, Park JW, Liu Y, Park YS, Kim JH, Yang H, et al. Sporadic Early-Onset Diffuse Gastric Cancers Have High Frequency of Somatic CDH1 Alterations, but Low Frequency of Somatic RHOA Mutations Compared With Late-Onset Cancers. Gastroenterology. 2017;153:536-49. e26.

68. Guilford P, Humar B, Blair V. Hereditary diffuse gastric cancer: translation of $\mathrm{CDH} 1$ germline mutations into clinical practice. Gastric cancer: official journal of the International Gastric Cancer Association the Japanese Gastric Cancer Association. 2010;13:1-10.

69. Li X, Wu WK, Xing R, Wong SH, Liu Y, Fang X, et al. Distinct Subtypes of Gastric Cancer Defined by Molecular Characterization Include Novel Mutational Signatures with Prognostic Capability. Cancer research. 2016;76:1724-32.

70. Hoesel B, Schmid JA. The complexity of NF-KB signaling in inflammation and cancer. Hoesel Schmid Molecular Cancer. 2013;12:86-100.

71. Lebrec H, Ponce R, Preston BD, Iles J, Born TL, Hooper M. Tumor necrosis factor, tumor necrosis factor inhibition, and cancer risk. Curr Med Res Opin. 2015;31:557-74.

72. Wang L, Zhao Y, Liu Y, Akiyama K, Chen C, Qu C, et al. IFN-gamma and TNF-alpha synergistically induce mesenchymal stem cell impairment and tumorigenesis via NFkappaB signaling. Stem cells. 2013;31:1383-95.

Page $10 / 31$ 


\section{Tables}

Table 1 Correlation between OS and clinicopathologic features of GC patients in TCGA cohort. 


\begin{tabular}{|c|c|c|c|c|}
\hline Variables & Events/total & MST (months) & HR (95\% CI) & P-value \\
\hline Age (years) & $144 / 348$ & 29 & & 0.022 \\
\hline$<60$ & $36 / 108$ & 60 & 1 & \\
\hline$\geq 60$ & $108 / 240$ & 26 & $1.55(1.06-2.27)$ & \\
\hline Missing & 3 & & & \\
\hline Gender & $144 / 351$ & 29 & & 0.178 \\
\hline Male & $100 / 226$ & 29 & 1 & \\
\hline Female & $44 / 125$ & 35 & $0.78(0.55-1.12)$ & \\
\hline Missing & 0 & & & \\
\hline Anatomic neoplasm & $138 / 337$ & 29 & & 0.919 \\
\hline Gastroesophageal junction & $36 / 84$ & 26 & 1 & \\
\hline Fundus gastric body & $50 / 123$ & 28 & $0.92(0.60-1.41)$ & \\
\hline Gastric antrum & $52 / 130$ & 35 & $0.94(0.61-1.43)$ & \\
\hline Missing & 14 & & & \\
\hline HP infection & $66 / 161$ & 43 & & 0.304 \\
\hline Positive & $6 / 18$ & 58 & 1 & \\
\hline Negative & $60 / 143$ & 43 & $1.55(0.67-3.61)$ & \\
\hline Missing & 190 & & & \\
\hline Histologic type & $144 / 350$ & 29 & & 0.057 \\
\hline Intestinal & $64 / 160$ & 38 & 1 & \\
\hline Diffuse type & 24/61 & 60 & $1.00(0.63-1.60)$ & \\
\hline Signet ring type & $8 / 11$ & 13 & $2.52(1.20-5.25)$ & \\
\hline Other types & $48 / 118$ & 26 & $1.29(0.88-1.88)$ & \\
\hline Missing & 1 & & & \\
\hline Histologic grade & $140 / 342$ & 29 & & 0.169 \\
\hline G1 & $2 / 9$ & NA & 1 & \\
\hline $\mathrm{G} 2$ & $48 / 127$ & 43 & $1.67(0.41-6.86)$ & \\
\hline G3 & $90 / 206$ & 26 & $2.22(0.55-9.01)$ & \\
\hline Missing & 9 & & & \\
\hline MSS1 & $144 / 350$ & 29 & & 0.225 \\
\hline MSI-H & $99 / 240$ & 28 & 1 & \\
\hline MSI-L & $22 / 51$ & 29 & $1.26(0.79-2.01)$ & \\
\hline MMS & $23 / 59$ & 35 & $0.76(0.48-1.19)$ & \\
\hline Missing & 1 & & & \\
\hline Pathological M & $138 / 336$ & 29 & & 0.012 \\
\hline M1 & $13 / 23$ & 12 & 1 & \\
\hline M0 & $125 / 313$ & 35 & $0.49(0.28-0.86)$ & \\
\hline Missing & 15 & & & \\
\hline Pathological N & $139 / 341$ & 29 & & 0.004 \\
\hline No & $28 / 103$ & 60 & 1 & \\
\hline $\mathrm{N}+$ & $111 / 238$ & 25 & $1.83(1.21-2.76)$ & \\
\hline Missing & 10 & & & \\
\hline Pathological T & $140 / 347$ & 31 & & 0.009 \\
\hline T1/T2 & 28/91 & 70 & 1 & \\
\hline T3/T4 & $112 / 256$ & 26 & $1.73(1.14-2.63)$ & \\
\hline Missing & 4 & & & \\
\hline TNM stage & $136 / 338$ & 29 & & $<0.001$ \\
\hline Stage I & $11 / 47$ & 73 & 1 & \\
\hline Stage II & $34 / 109$ & 56 & $1.61(0.81-3.18)$ & \\
\hline Stage III & $69 / 147$ & 26 & $2.44(1.29-4.61)$ & \\
\hline Stage IV & $22 / 35$ & 16 & $3.79(1.84-7.82)$ & \\
\hline Missing & 13 & & & \\
\hline Cancer status & $121 / 324$ & 37 & & $<0.001$ \\
\hline Tumor free & $35 / 206$ & NA & 1 & \\
\hline With tumor & $86 / 118$ & 17 & $5.53(3.70-8.26)$ & \\
\hline Missing & 27 & & & \\
\hline Primary therapy outcome & $114 / 303$ & 38 & & $<0.001$ \\
\hline CR & $55 / 209$ & 73 & 1 & \\
\hline PR & $4 / 5$ & 17 & $4.23(1.52-11.78)$ & \\
\hline $\mathrm{SD}$ & $7 / 25$ & 31 & $1.89(0.86-4.18)$ & \\
\hline PD & $48 / 64$ & 13 & $4.33(2.91-6.45)$ & \\
\hline Missing & 47 & & & \\
\hline
\end{tabular}




\begin{tabular}{|c|c|c|c|c|}
\hline Radiation therapy & $135 / 328$ & 31 & & 0.001 \\
\hline Yes & $19 / 62$ & NA & 1 & \\
\hline No & $116 / 266$ & 26 & $2.32(1.42-3.80)$ & \\
\hline Missing & 23 & & & \\
\hline Residual tumor & $121 / 316$ & 37 & & $<0.001$ \\
\hline R1 & $9 / 14$ & 13 & 1 & \\
\hline R2 & $12 / 14$ & 9 & $1.88(0.95-3.73)$ & \\
\hline R0 & $100 / 288$ & 47 & $7.19(3.88-13.34)$ & \\
\hline Missing & 35 & & & \\
\hline Targeted therapy & $134 / 326$ & 31 & & 0.022 \\
\hline Yes & $56 / 151$ & 43 & 1 & \\
\hline No & $78 / 175$ & 26 & $1.49(1.06-2.10)$ & \\
\hline Missing & 25 & & & \\
\hline
\end{tabular}

Abbreviations: OS, overall survival; GC, gastric cancer; TCGA, The Cancer Genome Atlas; HR, hazard ratio; MST, median survival time; G1, highly differentiated; G2, moderately differentiated; G3, poorly differentiated; MSI-H, microsatellite instability-altitude; MSI-L, Microsatellite instability-altitude; CR, complete response; PR, partial response; SD, stable disease; $\mathrm{PD}$, progressive disease; R1, microscopic residual tumor; R2, macroscopic residual tumor; R0, no residual tumor.

Table 2 Prognostic values of ADAMTS genes expression in GC OS of TCGA cohort.

\begin{tabular}{|c|c|c|c|c|c|c|}
\hline $\begin{array}{l}\text { Gene } \\
\text { expression }\end{array}$ & $\begin{array}{l}\text { Events/total } \\
(\mathrm{n}=351)\end{array}$ & $\begin{array}{l}\text { MST } \\
\text { (months) }\end{array}$ & $\begin{array}{l}\text { Crude HR } \\
(95 \% \text { CI })\end{array}$ & $\begin{array}{l}\text { Crude } \\
\text { P- } \\
\text { value } \\
\end{array}$ & $\begin{array}{l}\text { Adjusted HR } \\
(95 \% \mathrm{CI})\end{array}$ & $\begin{array}{l}\text { Adjusted P- } \\
\text { value }^{\mathrm{a}}\end{array}$ \\
\hline \multicolumn{7}{|c|}{ ADAMTS1 } \\
\hline Low & $61 / 176$ & 56 & \multirow{2}{*}{$\begin{array}{l}1 \\
1.52(1.09- \\
2.12)\end{array}$} & & \multirow{2}{*}{$\begin{array}{l}1 \\
1.39(0.91- \\
2.11)\end{array}$} & \\
\hline High & $83 / 175$ & 26 & & 0.013 & & 0.125 \\
\hline \multicolumn{7}{|c|}{$A D A M T S 2$} \\
\hline Low & $64 / 176$ & 47 & \multirow{2}{*}{$\begin{array}{l}1 \\
1.38(0.99- \\
1.92)\end{array}$} & & \multirow{2}{*}{$\begin{array}{l}1 \\
1.30(0.85- \\
1.98)\end{array}$} & \\
\hline High & $80 / 175$ & 26 & & 0.055 & & 0.226 \\
\hline \multicolumn{7}{|c|}{$A D A M T S 3$} \\
\hline Low & $63 / 176$ & 37 & \multirow{2}{*}{$\begin{array}{l}1 \\
1.25(0.90- \\
1.73)\end{array}$} & & \multirow{2}{*}{$\begin{array}{l}1 \\
1.36(0.88- \\
2.09)\end{array}$} & \\
\hline High & $81 / 175$ & 27 & & 0.19 & & 0.168 \\
\hline \multicolumn{7}{|l|}{ ADAMTS4 } \\
\hline Low & $63 / 176$ & 43 & \multirow{2}{*}{$\begin{array}{l}1 \\
1.21(0.87- \\
1.68)\end{array}$} & & \multirow{2}{*}{$\begin{array}{l}1 \\
1.34(0.87- \\
2.07)\end{array}$} & \\
\hline High & $81 / 175$ & 28 & & 0.266 & & 0.189 \\
\hline \multicolumn{7}{|l|}{ ADAMTS5 } \\
\hline Low & $70 / 176$ & 27 & \multirow{2}{*}{$\begin{array}{l}1 \\
1.09(0.79- \\
1.52)\end{array}$} & & \multirow{2}{*}{$\begin{array}{l}1 \\
0.84(0.54- \\
1.31)\end{array}$} & \\
\hline High & $74 / 175$ & 35 & & 0.599 & & 0.441 \\
\hline \multicolumn{7}{|l|}{ ADAMTS6 } \\
\hline Low & $59 / 176$ & 56 & \multirow{2}{*}{$\begin{array}{l}1 \\
1.80(1.29- \\
2.51)\end{array}$} & & \multirow{2}{*}{$\begin{array}{l}1 \\
1.89(1.19- \\
3.01)\end{array}$} & \\
\hline High & $85 / 175$ & 21 & & 0.001 & & 0.007 \\
\hline \multicolumn{7}{|l|}{ ADAMTS7 } \\
\hline Low & $64 / 176$ & 43 & \multirow{2}{*}{$\begin{array}{l}1 \\
1.33(0.95- \\
1.85)\end{array}$} & & \multirow{2}{*}{$\begin{array}{l}1 \\
1.41(0.91- \\
2.18)\end{array}$} & \\
\hline High & $80 / 175$ & 26 & & 0.095 & & 0.120 \\
\hline \multicolumn{7}{|l|}{ ADAMTS8 } \\
\hline Low & $67 / 176$ & 37 & \multirow{2}{*}{$\begin{array}{l}1 \\
1.15(0.83- \\
1.60) \\
\end{array}$} & & \multirow{2}{*}{$\begin{array}{l}1 \\
1.52(0.97- \\
2.39) \\
\end{array}$} & \\
\hline High & $77 / 175$ & 28 & & 0.401 & & 0.067 \\
\hline
\end{tabular}

Notes: ${ }^{a}$ Adjusted for age, TNM stage, cancer status, primary therapy outcome, residual tumor, targeted molecular therapy and radiation therapy.

Abbreviations: HR, hazard ratio; MST, median survival time; OS, overall survival.

Table 3 Stratified analysis of ADAMTS6 gene expression in clinicopathologic features of GC cases. 


\begin{tabular}{|c|c|c|c|}
\hline Variables & Cases & HR (95\% CI) & Log-rank P-value \\
\hline Age (years) & 348 & & \\
\hline$<60$ & 108 & $1.01(0.46-2.21)$ & 0.102 \\
\hline$\geq 60$ & 240 & $1.94(1.25-3.01)$ & 0.048 \\
\hline Gender & 351 & & \\
\hline Male & 226 & $1.66(1.05-2.62)$ & 0.021 \\
\hline Female & 125 & $2.26(1.14-4.50)$ & 0.293 \\
\hline \multicolumn{4}{|l|}{ Anatomic neoplasm } \\
\hline Gastroesophageal & 337 & & \\
\hline Junction & 84 & $0.79(0.29-2.15)$ & 0.501 \\
\hline Fundus gastric body & 123 & $0.70(0.39-1.24)$ & 0.001 \\
\hline Gastric antrum & 130 & 1.97(1.01-3.85) & 0.001 \\
\hline HP infection & 161 & & \\
\hline Positive & 18 & $3.61(0.22-59.81)$ & 0.180 \\
\hline Negative & 143 & $1.20(0.65-2.23)$ & 0.005 \\
\hline Histologic type & 350 & & \\
\hline Intestinal & 160 & $2.53(1.43-4.46)$ & $\mathrm{P}<0.001$ \\
\hline Diffuse type & 61 & $0.67(0.28-1.59)$ & 0.158 \\
\hline Signet ring type & 11 & $0.64(0.02-26.22)$ & 0.312 \\
\hline Other types & 118 & $1.96(1.01-3.82)$ & 0.005 \\
\hline Histologic grade & 342 & & \\
\hline G1 & 9 & NA & NA \\
\hline G2 & 127 & $1.15(0.59-2.26)$ & 0.006 \\
\hline G3 & 206 & 2.38(1.49-3.81) & $\mathrm{P}<0.001$ \\
\hline MSS1 & 350 & & \\
\hline MSI-H & 240 & 1.67(1.08-2.59) & $\mathrm{P}<0.001$ \\
\hline MSI-L & 51 & $2.15(0.81-5.73)$ & 0.099 \\
\hline MMS & 59 & $2.62(0.88-7.81)$ & 0.005 \\
\hline Pathological M & 336 & & \\
\hline M1 & 23 & $1.19(0.07-19.35)$ & 0.870 \\
\hline M0 & 313 & $1.63(1.12-2.38)$ & $\mathrm{P}<0.001$ \\
\hline Pathological N & $139 / 341$ & & \\
\hline No & 103 & $0.90(0.35-2.30)$ & 0.005 \\
\hline $\mathrm{N}+$ & $111 / 238$ & $2.20(1.41-3.42)$ & $\mathrm{P}<0.001$ \\
\hline Pathological T & 347 & & \\
\hline $\mathrm{T} 1 / \mathrm{T} 2$ & 91 & $0.60(0.24-1.51)$ & 0.118 \\
\hline T3/T4 & 256 & $2.24(1.44-3.50)$ & $\mathrm{P}<0.001$ \\
\hline Pathologic stage & $136 / 338$ & & \\
\hline Stage I & 47 & $1.60(0.48-5.29)$ & 0.402 \\
\hline Stage II & 109 & $1.55(0.79-3.07)$ & 0.478 \\
\hline Stage III & 147 & $2.00(1.16-3.44)$ & 0.039 \\
\hline Stage IV & 35 & $3.11(0.70-13.86)$ & 0.132 \\
\hline Cancer status & $121 / 324$ & & \\
\hline Tumor free & 206 & $2.26(1.07-4.80)$ & $\mathrm{P}<0.001$ \\
\hline With tumor & 118 & 1.71(1.06-2.76) & 0.108 \\
\hline Radiation therapy & $135 / 328$ & & \\
\hline Yes & 62 & $2.26(0.80-6.39)$ & 0.287 \\
\hline No & 266 & $1.75(1.78-2.59)$ & $\mathrm{P}<0.001$ \\
\hline Residual tumor & $121 / 316$ & & \\
\hline R1 & 14 & NA & NA \\
\hline $\mathrm{R} 2$ & 14 & $0.78(0.02-41.15)$ & 0.531 \\
\hline R0 & 288 & $1.71(1.13-2.58)$ & 0.090 \\
\hline Targeted therapy & $134 / 326$ & & \\
\hline Yes & 151 & $1.36(0.77-2.39)$ & 0.388 \\
\hline No & 175 & 1.92(1.18-3.12) & $\mathrm{P}<0.001$ \\
\hline
\end{tabular}

Abbreviations: ADAMTS, A Disintegrin and Metalloproteinase with Thrombospondin motifs; GC, gastric cancer; TCGA, The Cancer Genome Atlas; HP, Helicobacter Pylori; HR, hazard ratio; MST, median survival time; OS, overall survival; G1, highly differentiated; G2, moderately differentiated; G3, poorly differentiated; MSI-H, microsatellite instability-altitude; MSI-L, Microsatellite instability-altitude; CR, complete response; PR, partial response; $\mathrm{SD}$, stable disease; $\mathrm{PD}$, progressive disease; $\mathrm{T}$, tumour; $\mathrm{N}$, node; $\mathrm{M}$, metastasis; $\mathrm{R} 1$, microscopic 
residual tumor; R2, macroscopic residual tumor; R0, no residual tumor; CI, confidence interval; NA, Not Applicable.

Table 4 Joint effects survival analysis of clinical factors and the ADAMTS6 expression with OS.

\begin{tabular}{|c|c|c|c|c|c|c|c|c|}
\hline Group & ADAMTS6 & Variables & Events/total & $\begin{array}{l}\text { MST } \\
\text { (months) }\end{array}$ & $\begin{array}{l}\text { Crude HR } \\
(95 \% \mathrm{CI})\end{array}$ & $\begin{array}{l}\text { Crude } \\
\text { P- } \\
\text { value }\end{array}$ & $\begin{array}{l}\text { Adjusted } \\
\text { HR }(95 \% \\
\text { CI })\end{array}$ & $\begin{array}{l}\text { Adjusted } \\
\text { P- } \\
\text { value }^{\mathrm{a}}\end{array}$ \\
\hline \multicolumn{9}{|c|}{ Histologic grade } \\
\hline A & $\begin{array}{l}\text { Low } \\
\text { expression }\end{array}$ & $\mathrm{G} 1+\mathrm{G} 2$ & $27 / 74$ & 56 & 1 & & \multirow{4}{*}{$\begin{array}{l}1 \\
0.734(0.394- \\
1.371) \\
1.171(0.600- \\
2.286) \\
1.815(1.035- \\
3.184)\end{array}$} & \\
\hline B & $\begin{array}{l}\text { Low } \\
\text { expression }\end{array}$ & $\mathrm{G} 3+\mathrm{G} 4$ & $32 / 98$ & 47 & $1.005(0.602-1.680)$ & 0.984 & & 0.332 \\
\hline $\mathrm{C}$ & $\begin{array}{l}\text { High } \\
\text { expression }\end{array}$ & $\mathrm{G} 1+\mathrm{G} 2$ & $23 / 62$ & 31 & I.226(0.701-2.142) & 0.475 & & 0.644 \\
\hline $\mathrm{D}$ & $\begin{array}{l}\text { High } \\
\text { expression }\end{array}$ & $\mathrm{G} 3+\mathrm{G} 4$ & $58 / 108$ & 18 & $2.045(1.291-3.237)$ & 0.002 & & 0.038 \\
\hline \multicolumn{9}{|c|}{ Radiation therapy } \\
\hline a & $\begin{array}{l}\text { Low } \\
\text { expression }\end{array}$ & Yes & $6 / 31$ & 47 & 1 & & \multirow{4}{*}{$\begin{array}{l}1 \\
3.265(1.276- \\
8.353) \\
2.644(0.954- \\
7.324) \\
5.917(2.349- \\
14.900)\end{array}$} & \\
\hline $\mathrm{b}$ & $\begin{array}{l}\text { Low } \\
\text { expression }\end{array}$ & No & $47 / 131$ & 58 & $3.104(1.321-7.2940$ & 0.009 & & 0.014 \\
\hline $\mathrm{C}$ & $\begin{array}{l}\text { High } \\
\text { expression }\end{array}$ & Yes & $13 / 31$ & 20 & $2.821(1.071-7.432)$ & 0.036 & & 0.062 \\
\hline d & $\begin{array}{l}\text { High } \\
\text { expression }\end{array}$ & No & $69 / 135$ & 31 & $\begin{array}{l}5.665(2.434- \\
13.188)\end{array}$ & $<0.001$ & & $<0.001$ \\
\hline \multicolumn{9}{|c|}{ Radical resection } \\
\hline I & $\begin{array}{l}\text { Low } \\
\text { expression }\end{array}$ & R0 & $44 / 155$ & 70 & 1 & & \multirow{4}{*}{$\begin{array}{l}1 \\
3.308(0.931- \\
11.751) \\
2.055(1.349- \\
3.129) \\
3.485(1.719- \\
7.067)\end{array}$} & \\
\hline II & $\begin{array}{l}\text { Low } \\
\text { expression }\end{array}$ & $\mathrm{R} 1+\mathrm{R} 2$ & $5 / 9$ & 8 & $3.046(1.204-7.707)$ & 0.019 & & 0.064 \\
\hline IV & $\begin{array}{l}\text { High } \\
\text { expression }\end{array}$ & R0 & $56 / 133$ & 27 & $1.829(1.230-2.720)$ & 0.003 & & 0.001 \\
\hline III & $\begin{array}{l}\text { High } \\
\text { expression }\end{array}$ & $\mathrm{R} 1+\mathrm{R} 2$ & $16 / 19$ & 12 & $5.009(2.807-8.937)$ & $<0.001$ & & 0.001 \\
\hline \multicolumn{9}{|c|}{$\begin{array}{l}\text { Targeted } \\
\text { molecular } \\
\text { therapy }\end{array}$} \\
\hline $\mathrm{i}$ & $\begin{array}{l}\text { Low } \\
\text { expression }\end{array}$ & Yes & $22 / 74$ & 70 & 1 & & \multirow{4}{*}{$\begin{array}{l}1 \\
0.928(0.478- \\
1.801) \\
1.626(0.891- \\
2.966) \\
2.030(1.087- \\
3.793)\end{array}$} & \\
\hline ii & Low & No & $31 / 89$ & 47 & $1.400(0.810-2.420)$ & 0.228 & & 0.825 \\
\hline iii & $\begin{array}{l}\text { High } \\
\text { expression }\end{array}$ & Yes & $34 / 77$ & 29 & 1.829(1.068_3.133) & 0.028 & & 0.113 \\
\hline iv & $\begin{array}{l}\text { High } \\
\text { expression }\end{array}$ & No & $47 / 86$ & 18 & $3.002(1.802-5.001)$ & $<0.001$ & & 0.026 \\
\hline \multicolumn{9}{|l|}{ Stage } \\
\hline $\mathrm{E}$ & $\begin{array}{l}\text { Low } \\
\text { expression }\end{array}$ & $\mathrm{I}+\mathrm{II}$ & $24 / 89$ & 56 & 1 & & \multirow{4}{*}{$\begin{array}{l}1 \\
1.839(0.975- \\
3.469) \\
1.579(0.794- \\
3.142) \\
3.897(2.117- \\
7.176) \\
\end{array}$} & \\
\hline F & Low & $\mathrm{III}+\mathrm{IV}$ & $34 / 84$ & 47 & $1.398(0.829-2.358)$ & 0.209 & & 0.06 \\
\hline G & $\begin{array}{l}\text { High } \\
\text { expression }\end{array}$ & $\mathrm{I}+\mathrm{II}$ & $21 / 67$ & 60 & $1.214(0.675-2.181)$ & 0.517 & & \multirow{2}{*}{$\begin{array}{l}0.193 \\
<0.001\end{array}$} \\
\hline $\mathrm{H}$ & $\begin{array}{l}\text { High } \\
\text { expression }\end{array}$ & $\mathrm{III}+\mathrm{IV}$ & $57 / 98$ & 17 & $2.916(1.807-4.704)$ & $<0.001$ & & \\
\hline
\end{tabular}

Notes: ${ }^{a}$ Adjusted for histologic grade, radiation therapy, radical resection, targeted molecular therapy and stage.

Abbreviations: ADAMTS, A Disintegrin and Metalloproteinase with Thrombospondin motifs; GC, gastric cancer; HR, hazard ratio; MST, median survival time; OS, overall survival; CI, confidence interval.

Table 5 Survival analysis of ADAMTS gene mRNA expression in GC cases in KM plotter database. 


\begin{tabular}{llll}
\hline Gene/ Affymetrix ID & Low / high expression cases & HR $(95 \% \mathrm{CI})$ & P-value \\
\hline ADAMTS1/222486_s_at & $317 / 314$ & $1.68(1.35-2.09)$ & $2.9 \mathrm{e}-06$ \\
ADAMTS2/226311_at & $316 / 315$ & $1.49(1.2-1.85)$ & $3 \mathrm{e}-04$ \\
\hline ADAMTS3/214913_at & $448 / 428$ & $1.33(1.12-1.58)$ & 0.00091 \\
\hline ADAMTS4/214913_at & $448 / 428$ & $1.33(1.12-1.58)$ & 0.00091 \\
\hline ADAMTS5/235368_at & $317 / 314$ & $1.4(1.12-1.74)$ & 0.0024 \\
\hline ADAMTS6/237411_at & $319 / 312$ & $1.7(1.37-2.12)$ & $1.5 \mathrm{e}-06$ \\
\hline ADAMTS7/228911_at & $344 / 287$ & $1.63(1.32-2.03)$ & $7.2 \mathrm{e}-06$ \\
\hline ADAMTS8/235649_at & $316 / 315$ & $1.72(1.38-2.13)$ & $9.9 \mathrm{e}-07$ \\
\hline
\end{tabular}

Abbreviations: ADAMTS, A Disintegrin and Metalloproteinase with Thrombospondin motifs; GC, gastric cancer; HR, hazard ratio; KM, Kaplan-Meier; CI, confidence interval.

Table 6 Stratified analysis of ADAMTS gene mRNA in Lauren typing in Kaplan-Meier plotter.

\begin{tabular}{|c|c|c|c|c|}
\hline Gene & Lauren typing & Low / high expression cases & HR (95\%CI) & P-value \\
\hline \multirow[t]{3}{*}{ ADAMTS1 } & Intestinal & $136 / 133$ & $1.79(1.23-2.59)$ & 0.0019 \\
\hline & Diffuse & $120 / 120$ & $1.3(0.92-1.83)$ & 0.13 \\
\hline & Mixed & $14 / 15$ & $1.96(0.6-6.37)$ & 0.26 \\
\hline \multirow[t]{3}{*}{ ADAMTS2 } & Intestinal & $136 / 133$ & $1.55(1.08-2.23)$ & 0.017 \\
\hline & Diffuse & $120 / 120$ & $1.37(0.97-1.94)$ & 0.069 \\
\hline & Mixed & $14 / 15$ & $0.9(0.3-2.68)$ & 0.85 \\
\hline \multirow[t]{3}{*}{ ADAMTS3 } & Intestinal & $162 / 158$ & $1.55(1.13-2.13)$ & 0.0063 \\
\hline & Diffuse & $120 / 121$ & $1.35(0.96-1.9)$ & 0.088 \\
\hline & Mixed & $16 / 16$ & $2.72(0.92-8.06)$ & 0.061 \\
\hline \multirow[t]{3}{*}{ ADAMTS4 } & Intestinal & $162 / 158$ & $1.55(1.13-2.13)$ & 0.0063 \\
\hline & Diffuse & $120 / 121$ & $1.35(0.96-1.9)$ & 0.088 \\
\hline & Mixed & $16 / 16$ & $2.72(0.92-8.06)$ & 0.061 \\
\hline \multirow[t]{3}{*}{ ADAMTS5 } & Intestinal & $134 / 135$ & $1.23(0.85-1.77)$ & 0.27 \\
\hline & Diffuse & $120 / 120$ & $1.54(1.09-2.18)$ & 0.013 \\
\hline & Mixed & $14 / 15$ & $0.9(0.3-2.68)$ & 0.85 \\
\hline \multirow[t]{3}{*}{ ADAMTS6 } & Intestinal & $139 / 130$ & $1.81(1.26-2.62)$ & 0.0013 \\
\hline & Diffuse & $121 / 119$ & $1.3(0.93-1.83)$ & 0.13 \\
\hline & Mixed & $14 / 15$ & $0.74(0.25-2.24)$ & 0.6 \\
\hline \multirow[t]{3}{*}{ ADAMTS7 } & Intestinal & $147 / 122$ & $2.33(1.61-3.38)$ & $4.3 e-06$ \\
\hline & Diffuse & $133 / 107$ & $1.4(0.99-1.96)$ & 0.054 \\
\hline & Mixed & $16 / 13$ & $1.54(0.51-4.58)$ & 0.44 \\
\hline \multirow{3}{*}{ ADAMTS8 } & Intestinal & $134 / 135$ & $1.42(0.99-2.05)$ & 0.057 \\
\hline & Diffuse & $121 / 119$ & $1.34(0.95-1.89)$ & 0.093 \\
\hline & Mixed & $14 / 15$ & $2.21(0.68-7.21)$ & 0.18 \\
\hline
\end{tabular}

Abbreviations: HR, hazard ratio; CI, confidence interval.

Table 7 Stratified analysis of ADAMTS gene mRNA in stage in Kaplan-Meier plotter database. 


\begin{tabular}{|c|c|c|c|c|}
\hline Gene & Stage & Low / high expression cases & HR $(95 \% \mathrm{CI})$ & P-value \\
\hline \multirow{4}{*}{ ADAMTS1 } & $\mathrm{I}$ & $31 / 31$ & $1.95(0.6-6.4)$ & 0.26 \\
\hline & II & $69 / 66$ & $1.57(0.83-2.97)$ & 0.16 \\
\hline & III & 98/99 & $1.11(0.77-1.62)$ & 0.57 \\
\hline & IV & $70 / 70$ & $1.52(1.02-2.27)$ & 0.036 \\
\hline \multirow[t]{4}{*}{ ADAMTS2 } & I & $31 / 31$ & $0.26(0.07-0.96)$ & 0.03 \\
\hline & II & $68 / 67$ & $0.62(0.33-1.19)$ & 0.15 \\
\hline & III & $98 / 99$ & $1.56(1.07-2.28)$ & 0.02 \\
\hline & IV & $70 / 70$ & $1.29(0.87-1.91)$ & 0.2 \\
\hline \multirow{4}{*}{ ADAMTS3 } & I & $35 / 32$ & $1.18(0.43-3.23)$ & 0.75 \\
\hline & II & $70 / 70$ & $1.52(0.83-2.76)$ & 0.17 \\
\hline & III & $152 / 153$ & $1.13(0.85-1.5)$ & 0.4 \\
\hline & IV & $74 / 74$ & $1.46(1-2.15)$ & 0.051 \\
\hline \multirow[t]{4}{*}{ ADAMTS4 } & I & $35 / 32$ & $1.18(0.43-3.23)$ & 0.75 \\
\hline & II & $70 / 70$ & $1.52(0.83-2.76)$ & 0.17 \\
\hline & III & $152 / 153$ & $1.13(0.85-1.5)$ & 0.4 \\
\hline & IV & $74 / 74$ & $1.46(1-2.15)$ & 0.051 \\
\hline \multirow[t]{4}{*}{ ADAMTS5 } & I & $31 / 31$ & $0.48(0.16-1.49)$ & 0.19 \\
\hline & II & $68 / 67$ & $1.66(0.86-3.18)$ & 0.13 \\
\hline & III & 98/99 & $1.81(1.24-2.64)$ & 0.002 \\
\hline & IV & $71 / 69$ & $1.51(1.02-2.25)$ & 0.04 \\
\hline \multirow[t]{4}{*}{ ADAMTS6 } & I & $32 / 30$ & $0.41(0.12-1.33)$ & 0.12 \\
\hline & II & $68 / 67$ & $1.4(0.74-2.63)$ & 0.29 \\
\hline & III & 98/99 & $1.36(0.93-1.98)$ & 0.11 \\
\hline & IV & $70 / 70$ & $1.31(0.88-1.95)$ & 0.18 \\
\hline \multirow{4}{*}{ ADAMTS7 } & I & $34 / 28$ & $2.56(0.77-8.56)$ & 0.11 \\
\hline & II & $82 / 53$ & $1.35(0.71-2.57)$ & 0.35 \\
\hline & III & $110 / 87$ & $1.77(1.21-2.57)$ & 0.0026 \\
\hline & IV & $74 / 66$ & $1.76(1.18-2.63)$ & 0.0047 \\
\hline \multirow[t]{4}{*}{ ADAMTS8 } & I & $31 / 31$ & $1.87(0.56-6.23)$ & 0.3 \\
\hline & II & $68 / 67$ & $1.52(0.8-2.88)$ & 0.19 \\
\hline & III & $98 / 99$ & $1.2(0.82-1.74)$ & 0.34 \\
\hline & IV & $70 / 70$ & $1.4(0.94-2.09)$ & 0.096 \\
\hline
\end{tabular}

Abbreviations: $\mathrm{HR}$, hazard ratio; CI, confidence interval.

Table 8 Stratified analysis of ADAMTS gene mRNA in degree of tumor differentiation in Kaplan-Meier plotter. 


\begin{tabular}{|c|c|c|c|c|}
\hline Gene & Differentiation & Low / high expression cases & HR (95\%CI) & P-value \\
\hline \multirow{3}{*}{ ADAMTS1 } & G1 & $2 / 3$ & 1142066032.99 (0 - Inf) & 0.41 \\
\hline & $\mathrm{G} 2$ & $34 / 33$ & $0.89(0.46-1.7)$ & 0.72 \\
\hline & G3 & $60 / 61$ & $0.87(0.53-1.4)$ & 0.55 \\
\hline \multirow[t]{3}{*}{ ADAMTS2 } & G1 & $2 / 3$ & 1142066039.57 (0 - Inf) & 0.41 \\
\hline & $\mathrm{G} 2$ & $34 / 33$ & $1.31(0.69-2.52)$ & 0.41 \\
\hline & G3 & $60 / 61$ & $1.34(0.82-2.18)$ & 0.24 \\
\hline \multirow[t]{3}{*}{ ADAMTS3 } & G1 & $16 / 16$ & $1.52(0.64-3.61)$ & 0.34 \\
\hline & $\mathrm{G} 2$ & $34 / 33$ & $1.35(0.71-2.59)$ & 0.36 \\
\hline & G3 & $82 / 83$ & $1.23(0.82-1.83)$ & 0.32 \\
\hline \multirow[t]{3}{*}{ ADAMTS4 } & G1 & $16 / 16$ & $1.52(0.64-3.61)$ & 0.34 \\
\hline & $\mathrm{G} 2$ & $34 / 33$ & $1.35(0.71-2.59)$ & 0.36 \\
\hline & G3 & $82 / 83$ & $1.23(0.82-1.83)$ & 0.32 \\
\hline \multirow{3}{*}{ ADAMTS5 } & G1 & $2 / 3$ & 1142066032.99 (0 - Inf) & 0.41 \\
\hline & $\mathrm{G} 2$ & $34 / 33$ & $0.96(0.5-1.84)$ & 0.91 \\
\hline & G3 & $60 / 61$ & $1.16(0.72-1.88)$ & 0.54 \\
\hline \multirow[t]{3}{*}{ ADAMTS6 } & G1 & $2 / 3$ & 1142066039.57 (0 - Inf) & 0.41 \\
\hline & G2 & $36 / 31$ & $1.49(0.78-2.84)$ & 0.23 \\
\hline & G3 & $62 / 59$ & $1.07(0.66-1.73)$ & 0.78 \\
\hline \multirow[t]{3}{*}{ ADAMTS7 } & G1 & $2 / 3$ & $1142066042.6(0-\mathrm{Inf})$ & 0.41 \\
\hline & G2 & $40 / 27$ & $2.39(1.24-4.59)$ & 0.0074 \\
\hline & G3 & $60 / 61$ & $0.77(0.48-1.26)$ & 0.3 \\
\hline \multirow[t]{3}{*}{ ADAMTS8 } & G1 & $2 / 3$ & 1142066039.57 (0 - Inf) & 0.41 \\
\hline & G2 & $34 / 33$ & $1.43(0.75-2.74)$ & 0.28 \\
\hline & G3 & $60 / 61$ & $1.1(0.68-1.79)$ & 0.69 \\
\hline
\end{tabular}

Abbreviations: HR, hazard ratio; CI, confidence interval.

Table 9 Stratified analysis of ADAMTS genes mRNA in treatment method in Kaplan-Meier plotter.

\begin{tabular}{lllll}
\hline Gene & Treatment method & Low / high expression cases & HR $(95 \% \mathrm{CI})$ & P-value \\
\hline ADAMTS1 & Surgery & $189 / 191$ & $1.66(1.24-2.22)$ & 0.00065 \\
& 5-FU & $17 / 17$ & $0.99(0.4-2.47)$ & 0.98 \\
\hline ADAMTS2 & Surgery & $192 / 188$ & $1.32(0.99-1.76)$ & 0.061 \\
& 5-FU & $17 / 17$ & $2.26(0.89-5.76)$ & 0.08 \\
\hline ADAMTS3 & Surgery & $194 / 186$ & $1.54(1.15-2.06)$ & 0.0032 \\
& 5-FU & $77 / 76$ & $0.88(0.63-1.24)$ & 0.47 \\
\hline ADAMTS4 & Surgery & $194 / 186$ & $1.54(1.15-2.06)$ & 0.0032 \\
& 5-FU & $77 / 76$ & $0.88(0.63-1.24)$ & 0.47 \\
\hline ADAMTS5 & Surgery & $190 / 190$ & $1.28(0.96-1.71)$ & 0.096 \\
& 5-FU & $17 / 17$ & $0.68(0.27-1.71)$ & 0.42 \\
\hline ADAMTS6 & Surgery & $190 / 190$ & $1.75(1.31-2.34)$ & 0.00014 \\
& 5-FU & $17 / 17$ & $2.04(0.81-5.16)$ & 0.12 \\
\hline ADAMTS7 & Surgery & $209 / 171$ & $1.57(1.17-2.09)$ & 0.0021 \\
& 5-FU & $17 / 17$ & $1(0.4-2.47)$ & 1 \\
\hline \multirow{2}{*}{ ADAMTS8 } & Surgery & $190 / 190$ & $1.48(1.11-1.98)$ & 0.0075 \\
& 5-FU & $17 / 17$ & $2.25(0.85-5.95)$ & 0.094 \\
\hline
\end{tabular}

Abbreviations: HR, hazard ratio; CI, confidence interval.

Table 10 Stratified analysis of ADAMTS gene mRNA in HER2 state in Kaplan-Meier Plotter database. 


\begin{tabular}{|c|c|c|c|c|}
\hline Gene & HER2 state & Low / high expression cases & HR $(95 \% \mathrm{CI})$ & P-value \\
\hline \multirow{2}{*}{$A D A M T S 1$} & Negative & $214 / 215$ & $1.6(1.23-2.1)$ & 0.00049 \\
\hline & Positive & $101 / 101$ & $1.94(1.32-2.84)$ & 0.00063 \\
\hline \multirow[t]{2}{*}{$A D A M T S 2$} & Negative & $214 / 215$ & $1.46(1.12-1.91)$ & 0.0049 \\
\hline & Positive & $101 / 101$ & $1.59(1.09-2.32)$ & 0.015 \\
\hline \multirow[t]{2}{*}{ ADAMTS3 } & Negative & $266 / 266$ & $1.49(1.19-1.87)$ & 0.00053 \\
\hline & Positive & $172 / 172$ & $1.26(0.97-1.63)$ & 0.082 \\
\hline \multirow[t]{2}{*}{ ADAMTS4 } & Negative & $266 / 266$ & $1.49(1.19-1.87)$ & 0.00053 \\
\hline & Positive & $172 / 172$ & $1.26(0.97-1.63)$ & 0.082 \\
\hline \multirow[t]{2}{*}{ ADAMTS5 } & Negative & $216 / 213$ & $1.44(1.1-1.87)$ & 0.0077 \\
\hline & Positive & $102 / 100$ & $1.37(0.94-1.99)$ & 0.1 \\
\hline \multirow[t]{2}{*}{ ADAMTS6 } & Negative & $215 / 214$ & $1.75(1.33-2.29)$ & $4.2 \mathrm{e}-05$ \\
\hline & Positive & $101 / 101$ & $1.59(1.09-2.31)$ & 0.015 \\
\hline \multirow[t]{2}{*}{ ADAMTS7 } & Negative & $225 / 204$ & $1.85(1.42-2.43)$ & $4.6 e-06$ \\
\hline & Positive & $104 / 98$ & $1.33(0.92-1.93)$ & 0.13 \\
\hline \multirow[t]{2}{*}{ ADAMTS8 } & Negative & $214 / 215$ & $1.75(1.34-2.29)$ & $3.7 e-05$ \\
\hline & Positive & $101 / 101$ & $1.64(1.12-2.38)$ & 0.0096 \\
\hline
\end{tabular}

Abbreviations: HR, hazard ratio; CI, confidence interval.

\section{Figures}

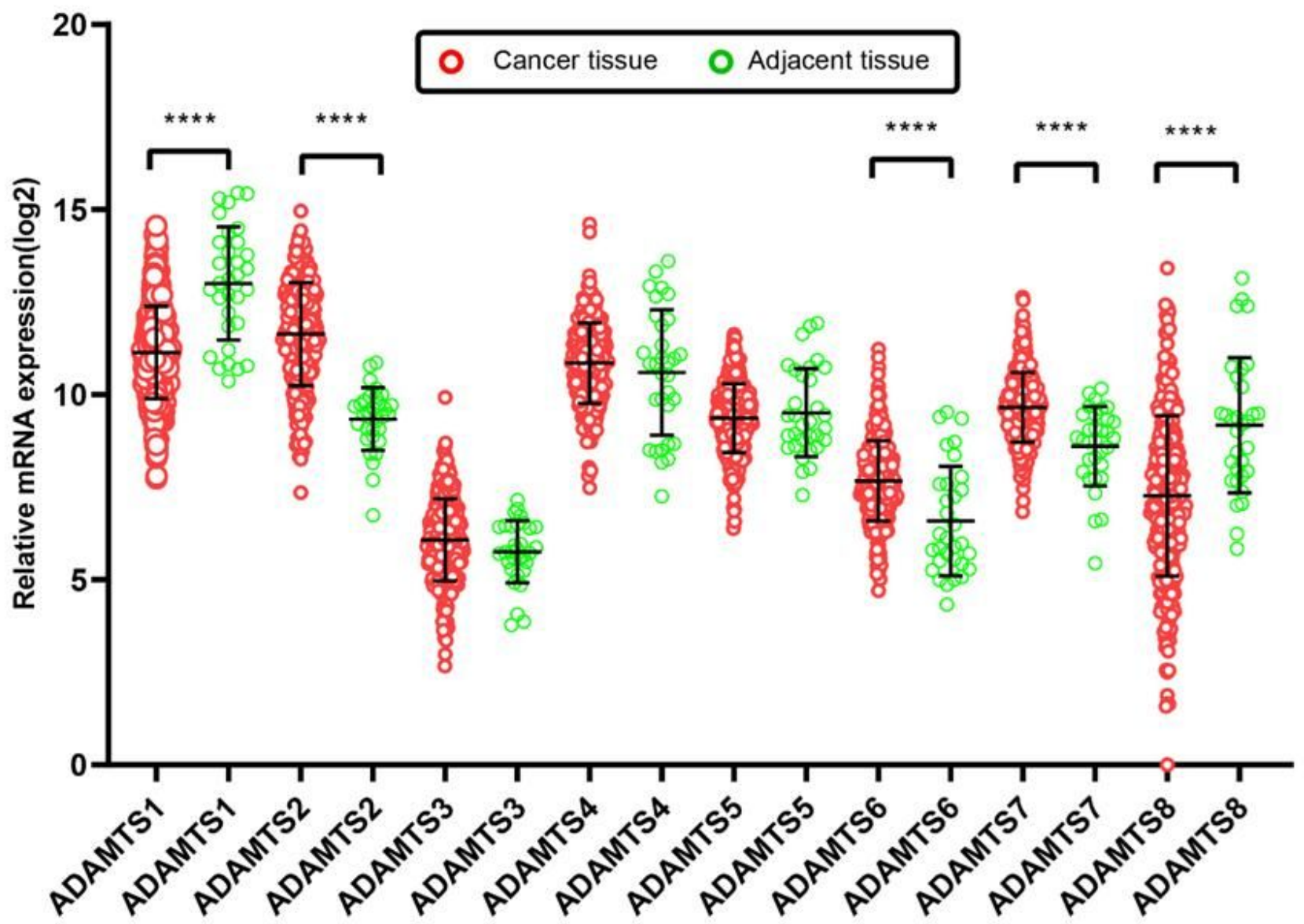

Figure 1

The scatter plot of ADAMTS mRNA expression in GC and adjacent tissues based on TCGA. Notes: ${ }^{\star} P<0.05,{ }^{\star \star} P<0.01$, ${ }^{\star \star \star} \mathrm{P}<$ $0.001, * \star * * P<0.0001$. 


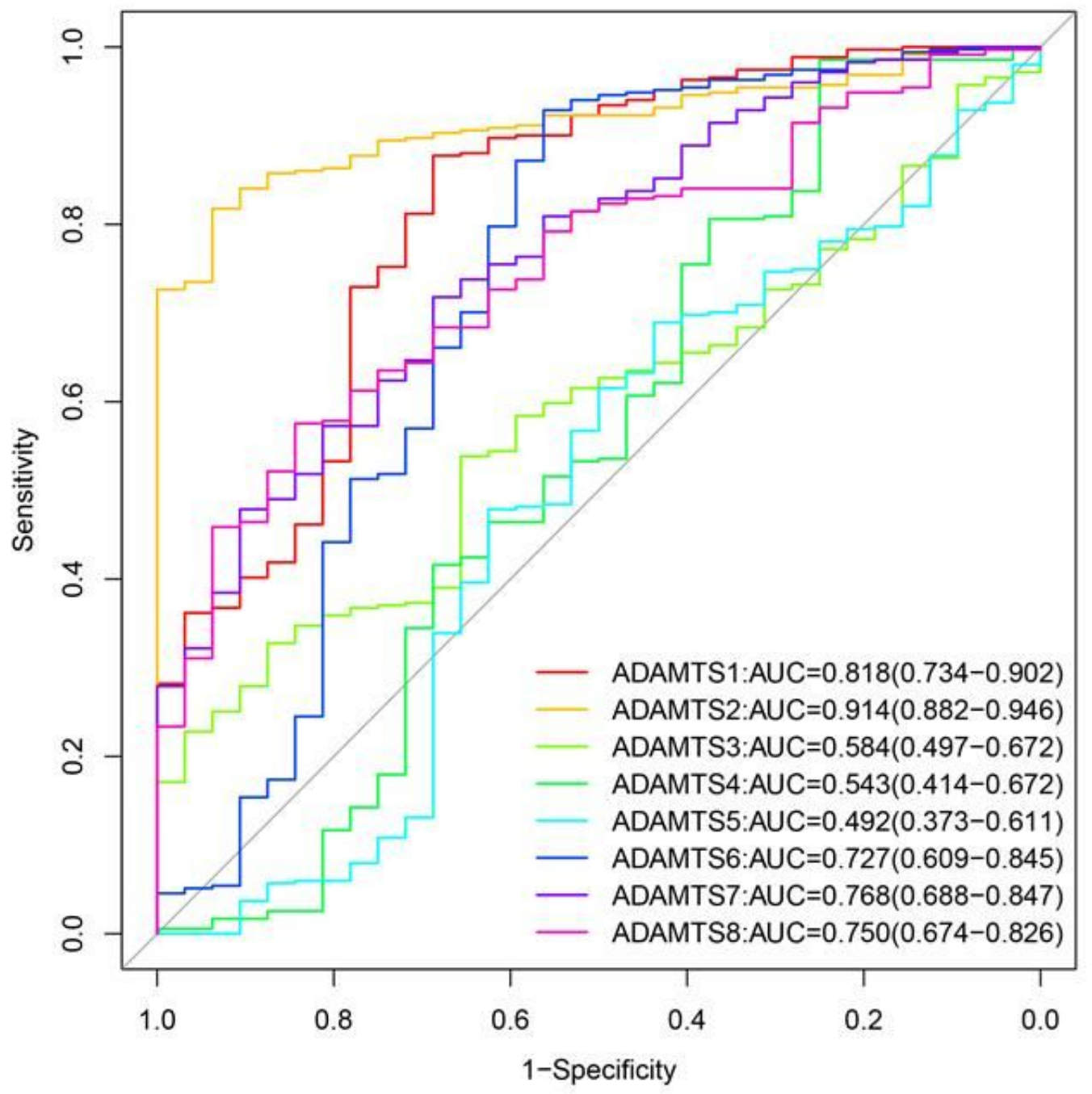

Figure 2

The ROC curve of ADAMTS mRNA expression in GC and adjacent tissues based on TCGA. 


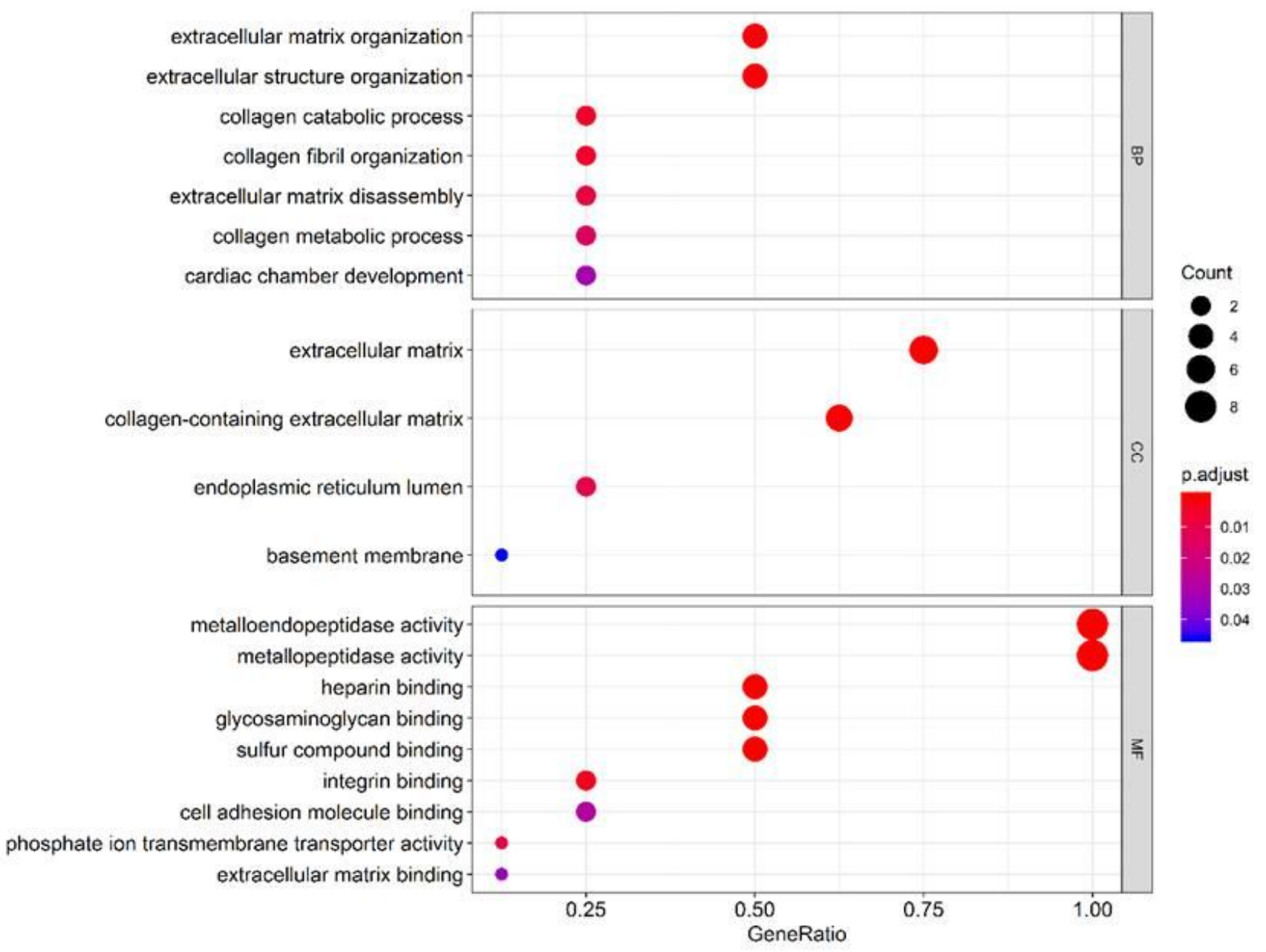

Figure 3

GO enrichment analysis of ADAMTS genes. 

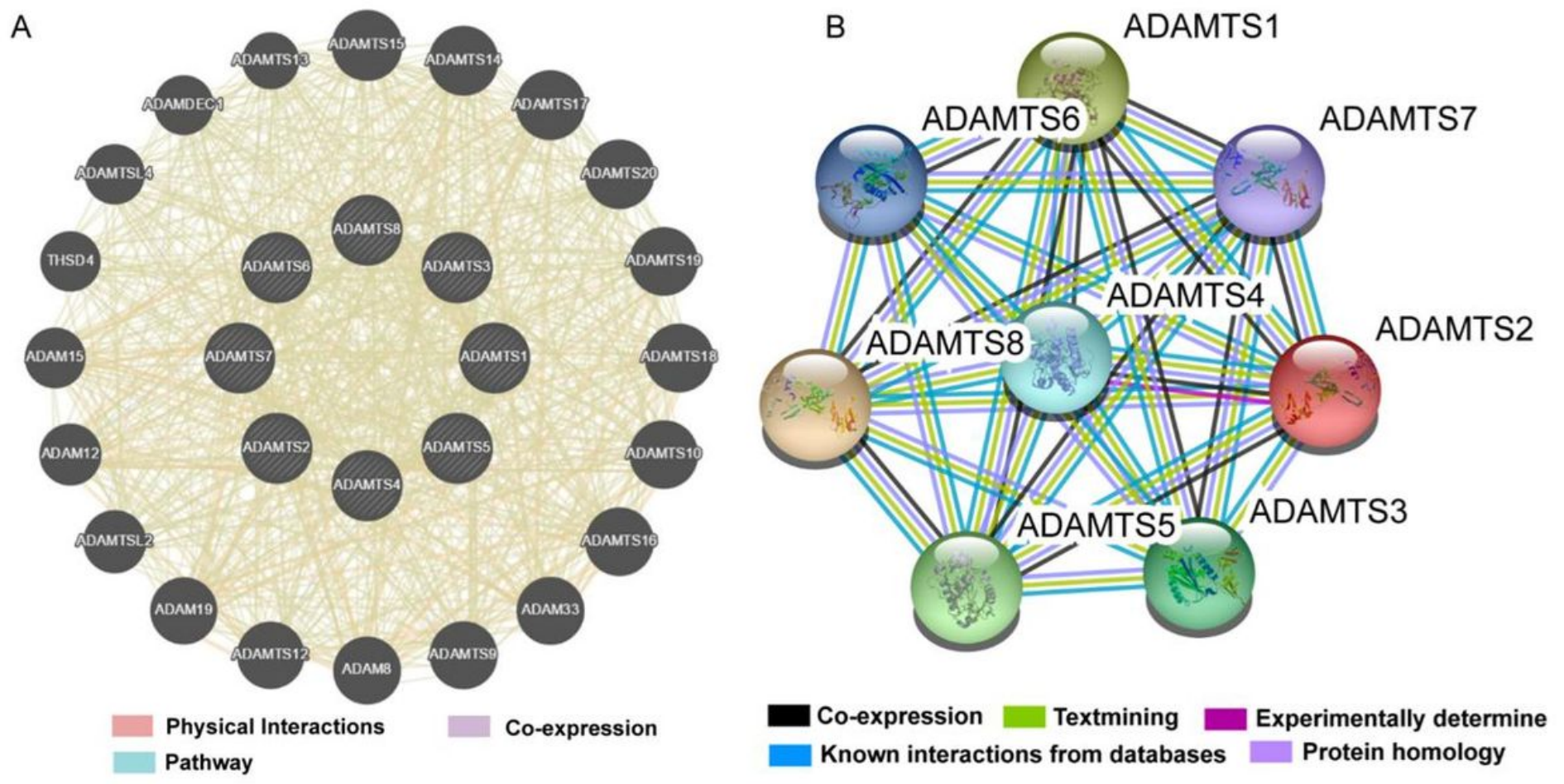

Figure 4

Gene and protein interaction networks of ADAMTS genes. Notes: (A) Gene multiple association network integration algorithm; (B) Protein-protein interaction networks. 


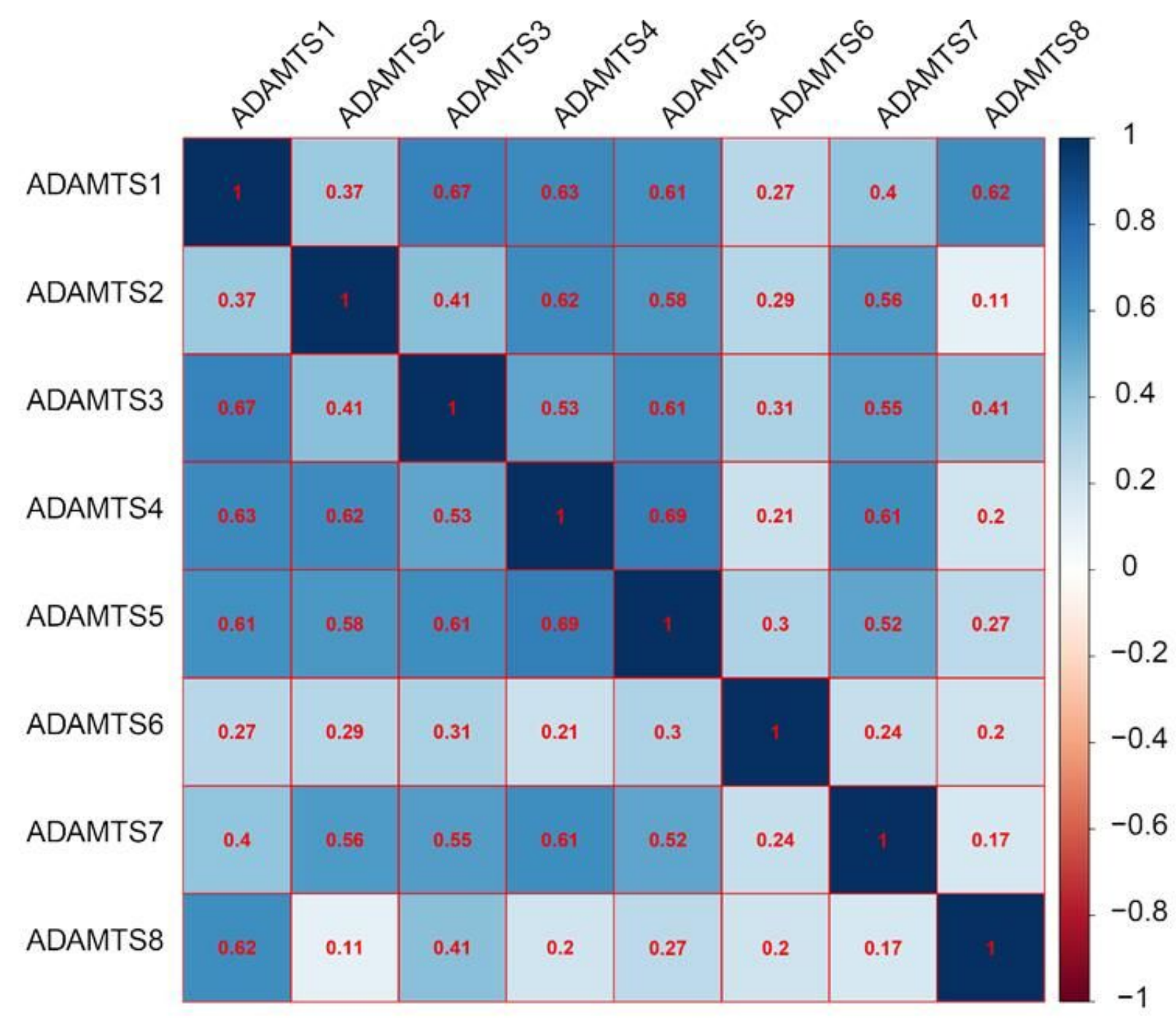

Figure 5

Co-expression matrix of ADAMTS genes in GC tumor tissues. 
A

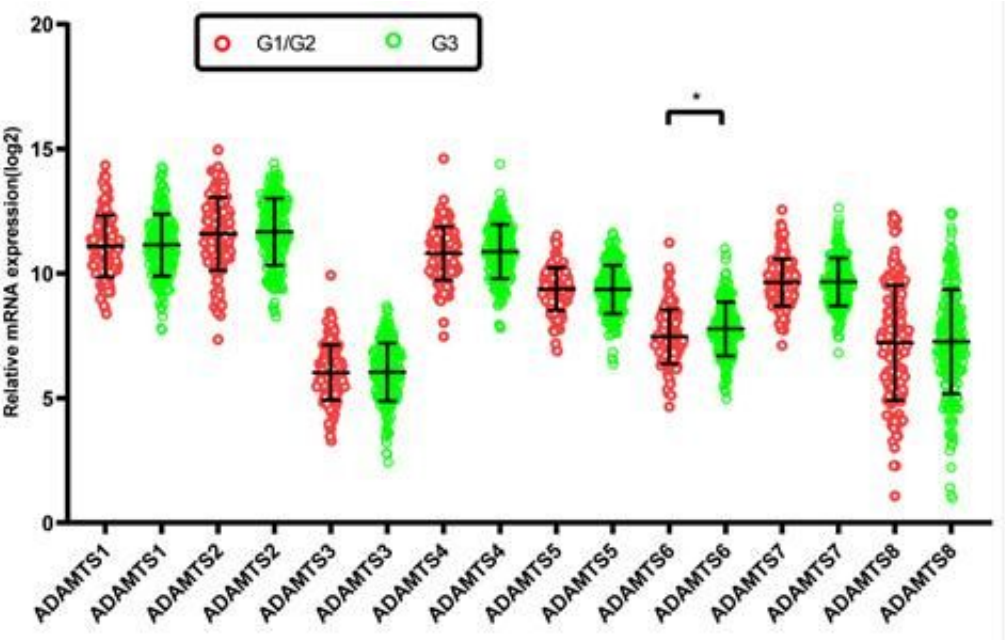

B

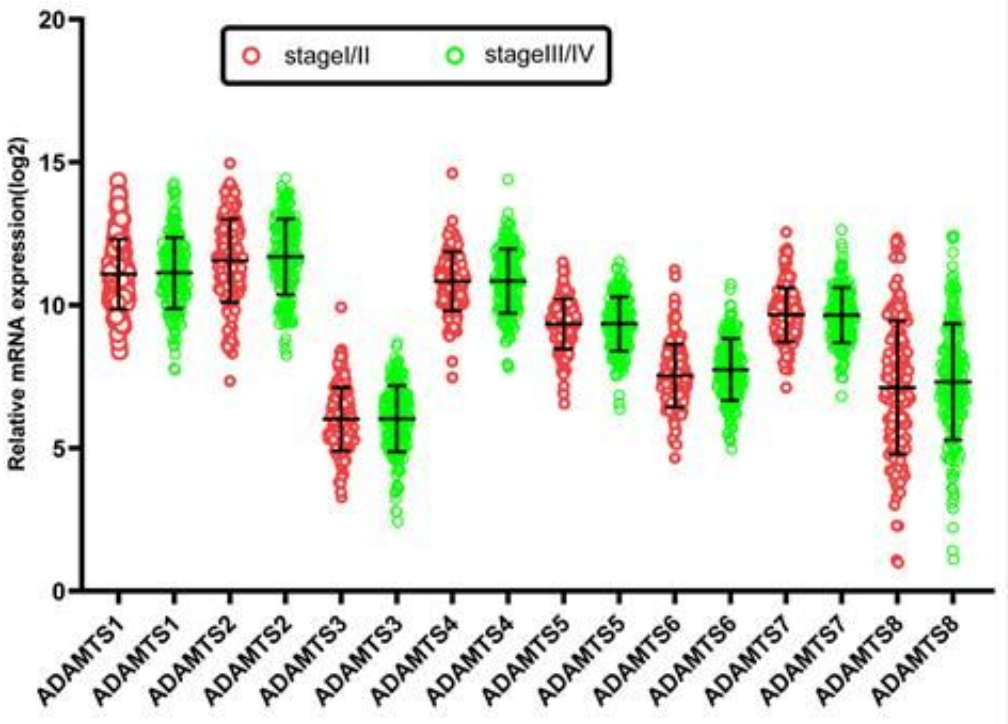

Figure 6

Gene expression distribution of ADAMTS genes in different GC histologic grades and tumor stages. Notes: (A) gene expression distribution of ADAMTS genes in different GC histologic grades; (B) gene expression distribution of ADAMTS genes in different GC tumor stages. $* \mathrm{P}<0.05$. 

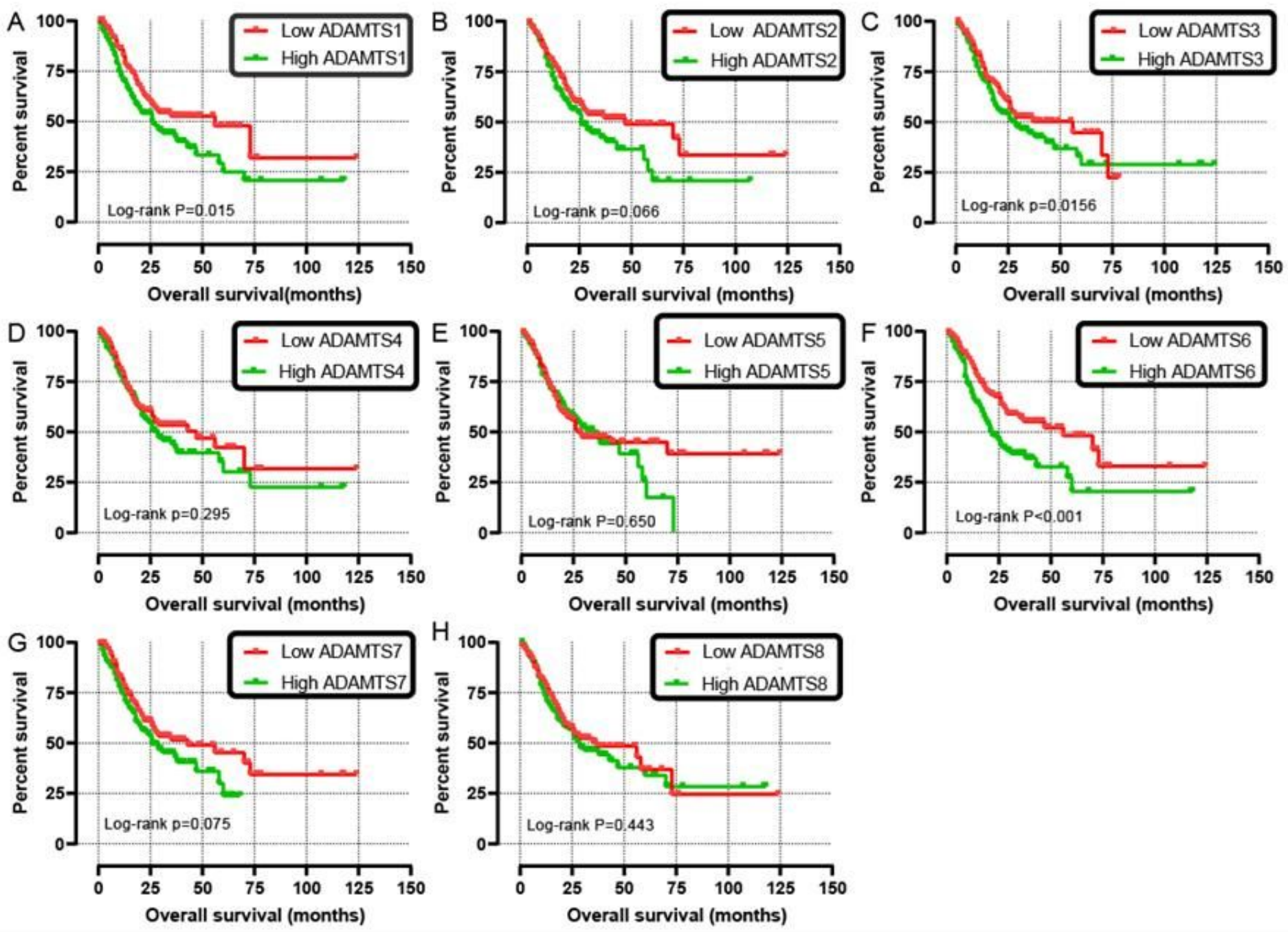

Figure 7

Kaplan-Meier survival curves for ADAMTS genes in GC of TCGA cohort. Notes: Overall survival stratified by ADAMTS1 (A), ADAMTS2 (B), ADAMTS3 (C), ADAMTS4 (D), ADAMTS5 (E), ADAMTS6 (F), ADAMTS7 (G), ADAMTS8 (H). 

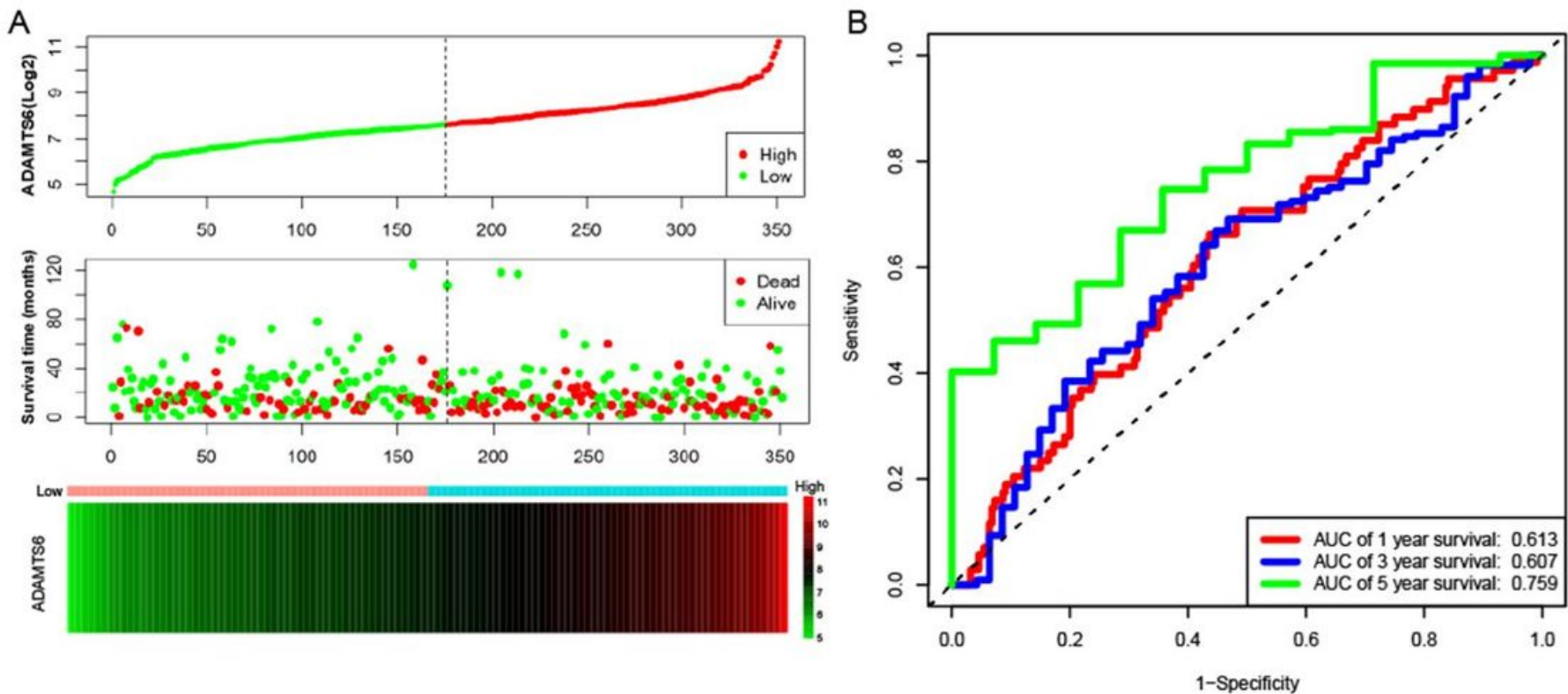

Figure 8

Prognostic value evaluation of ADAMTS6 in patients with GC. Notes: (A) From top to bottom are the expression values of ADAMTS6, patients' survival status distribution, and the expression heat map of ADAMTS6 in the low- and high-expression groups. (B) Receiver operating characteristic curve for predicting overall survival in GC patients by the ADAMTS6.
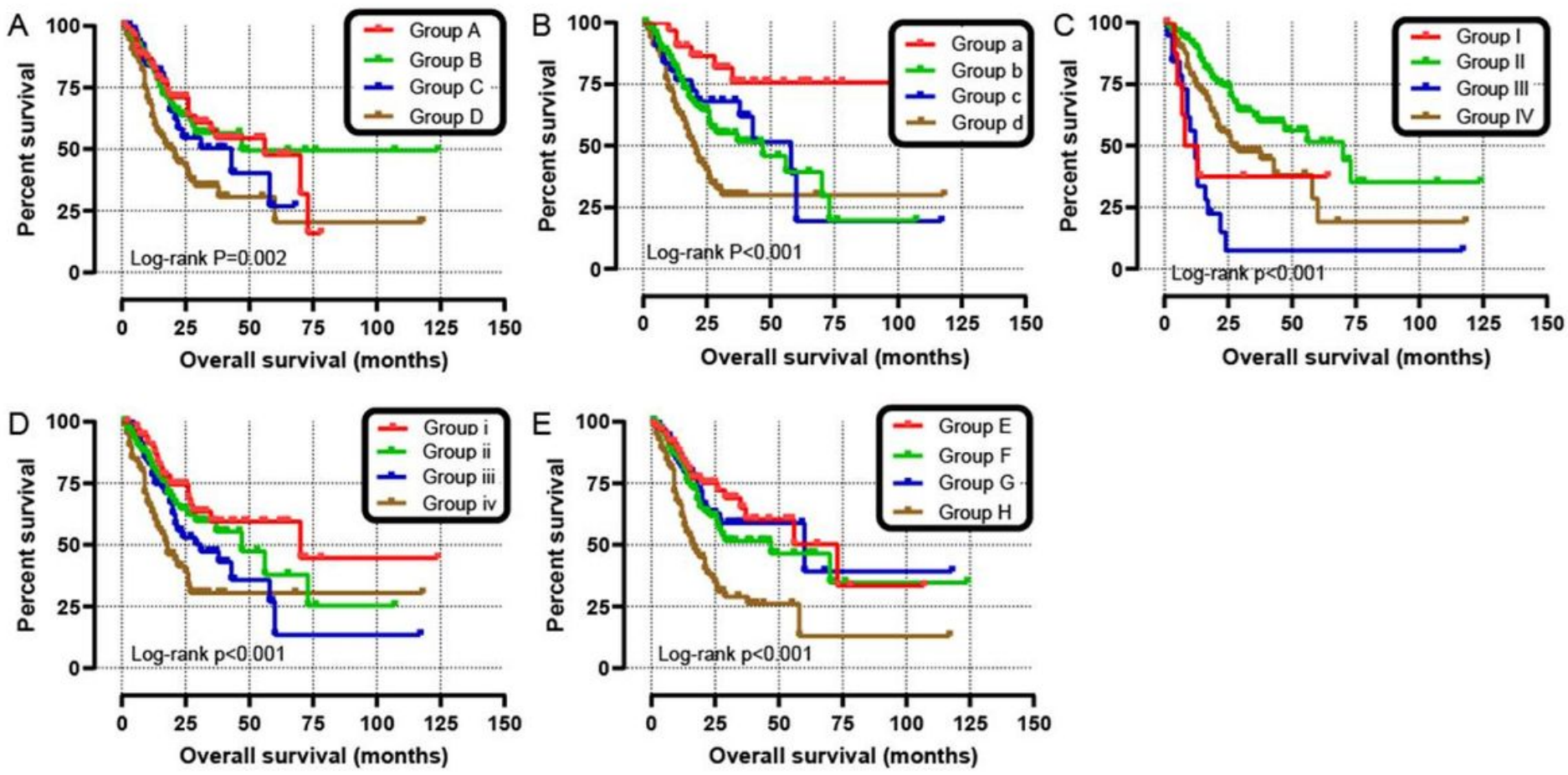

Figure 9

Joint effects analysis of overall survival stratified by ADAMTS6 and GC clinical parameters. Notes: Joint effects analysis stratified by ADAMTS6 and following clinical parameters: histologic grade (A), radiation therapy (B), radical resection (C), targeted molecular therapy (D), stage (E). 
A

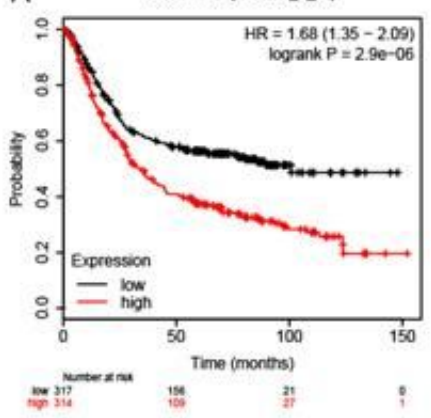

D ADAMTS.4 (214913_at)

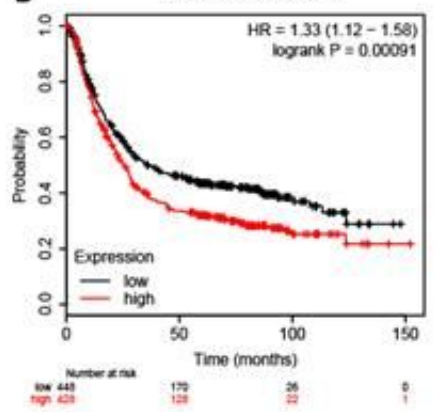

G

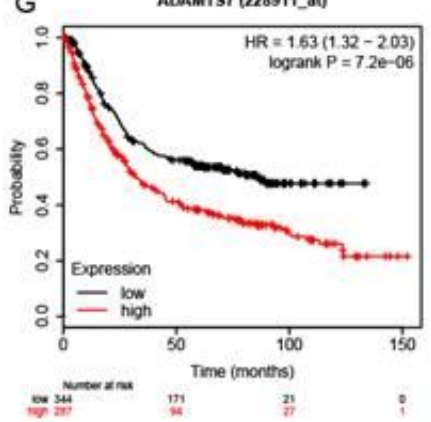

B
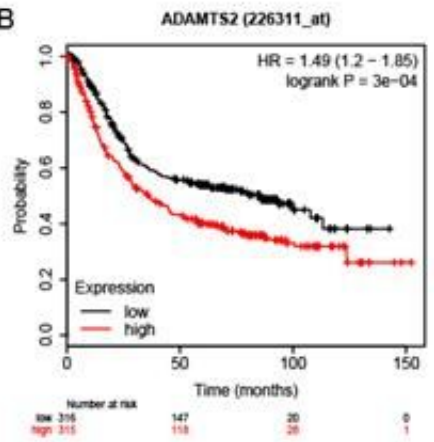

E

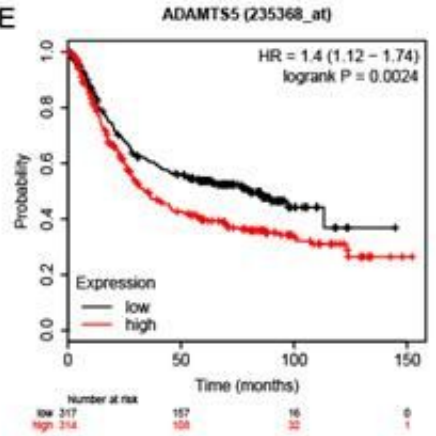

$\mathrm{H}$

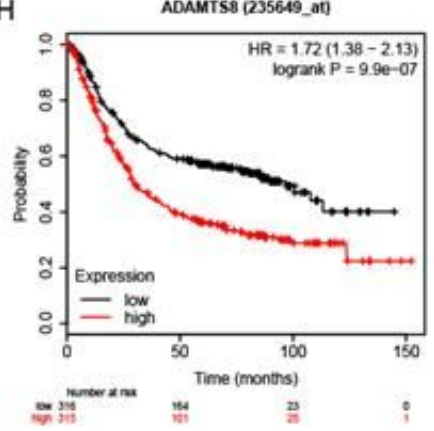

C
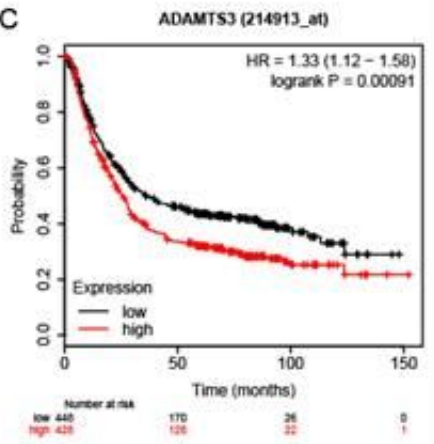

F

ADAMTS6 (237411_at)

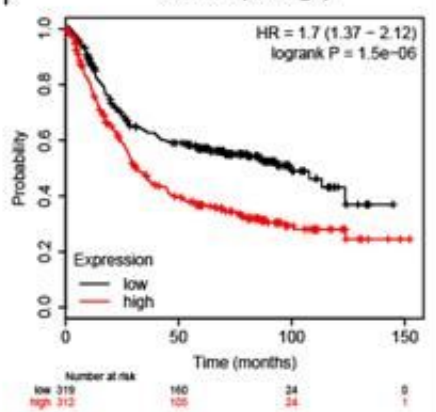

Figure 10

Survival analysis of ADAMTS mRNA expression in GC based on KM plotter Database. Notes: Survival analysis of ADAMTS1 (A), ADAMTS2 (B), ADAMTS3 (C), ADAMTS4 (D), ADAMTS5 (E), ADAMTS6 (F), ADAMTS7 (G), ADAMTS8 (H). 

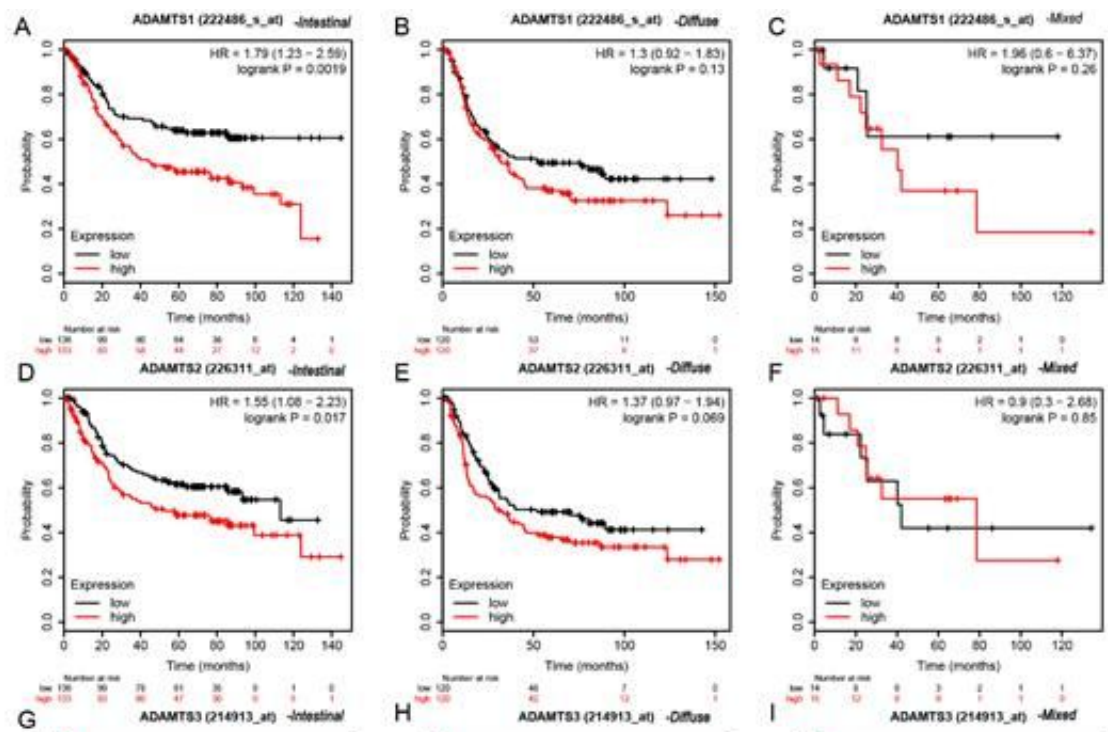

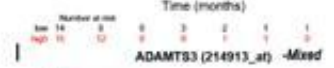
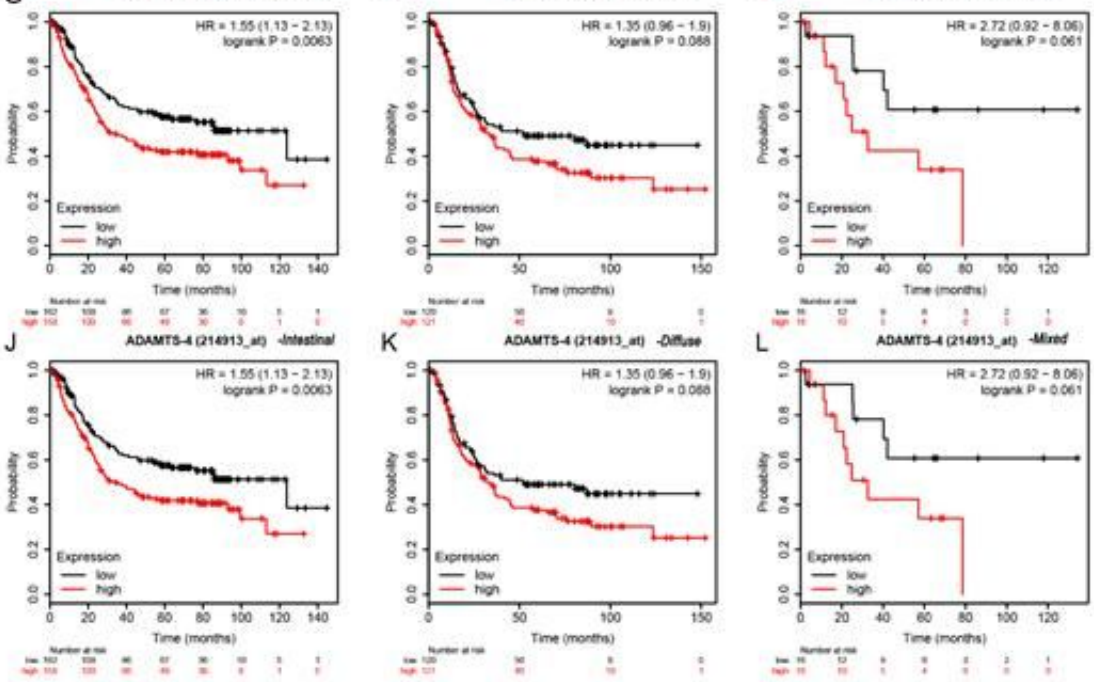

Figure 11

Stratified analysis of ADAMTS1-4 gene mRNA in Lauren typing of GC cases in KM plotter. 

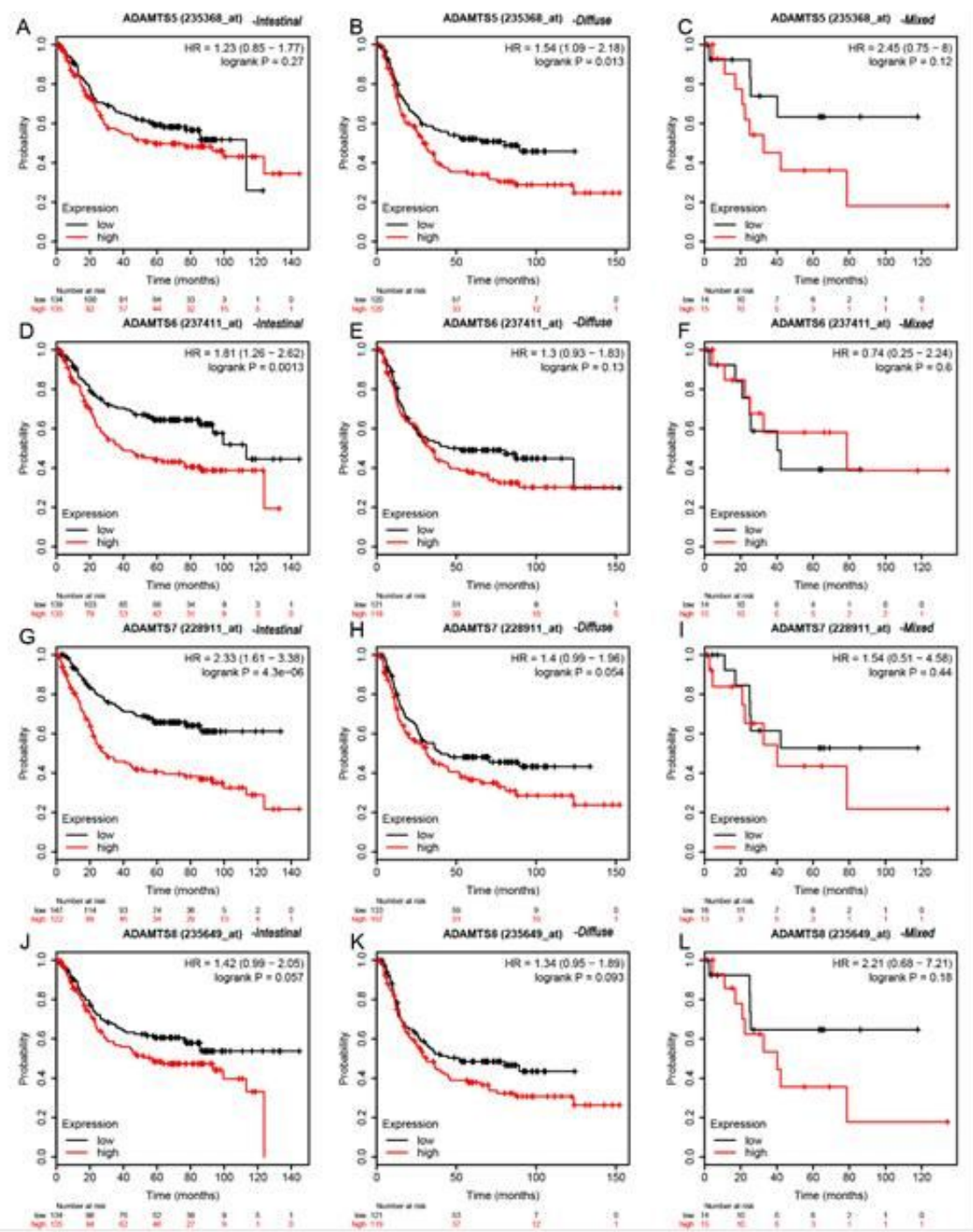

Figure 12

Stratified analysis of ADAMTS5-8 gene mRNA in Lauren typing of GC cases in KM plotter. 
A
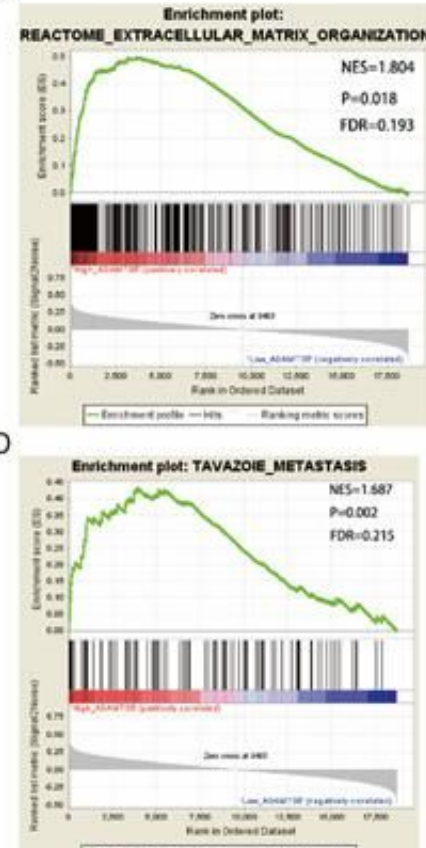

G

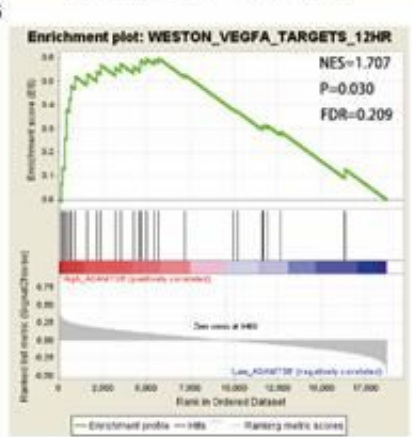

Enrkhment plot:

VECCHI_GASTRIC_CANCER_AOVANCED_VS_EARLY_U

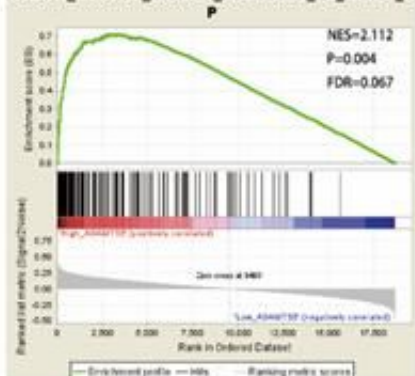

$\mathrm{E}$

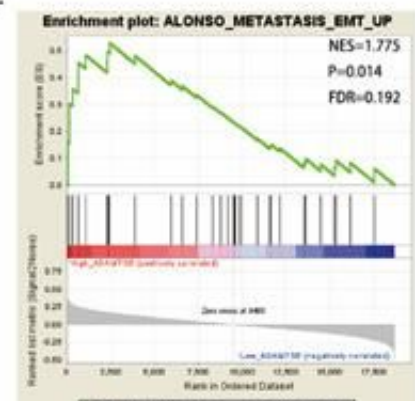

$\mathrm{H}$

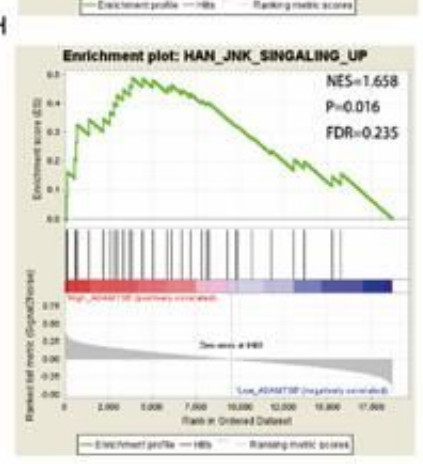

C

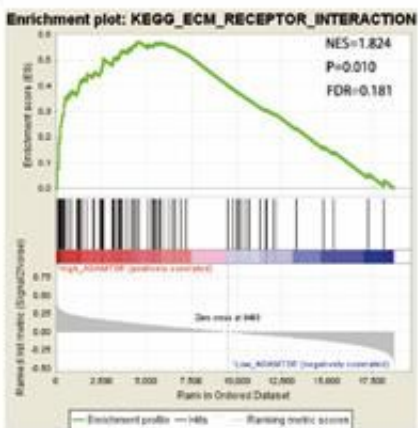

$\mathrm{F}$

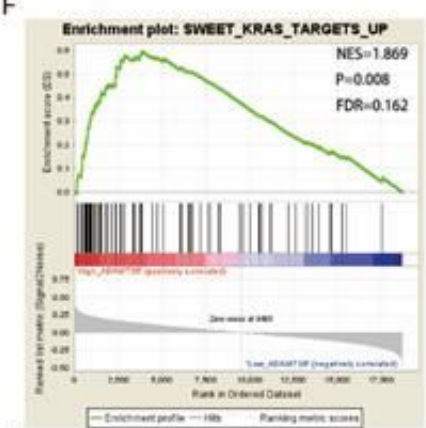

1

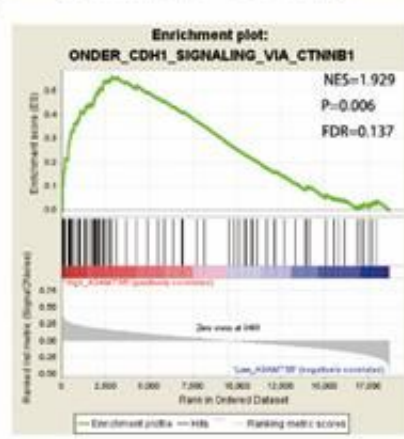

Figure 13

Gene set enrichment analysis (GSEA) of $\mathrm{C} 2$ gene sets for high ADAMTS6 expression groups. 
A

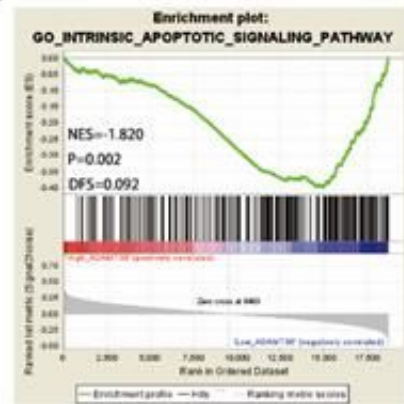

D

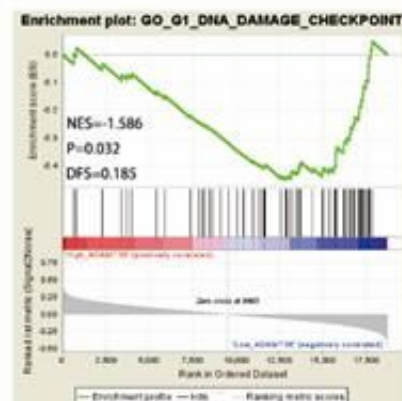

G

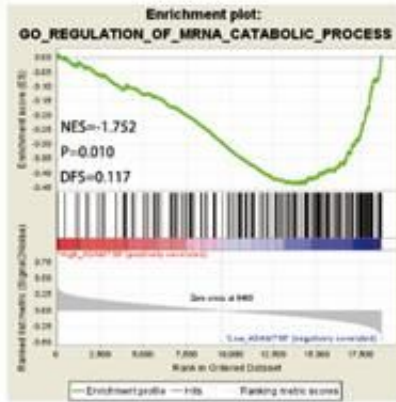

B

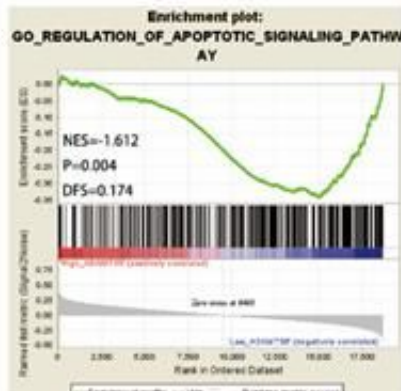

E

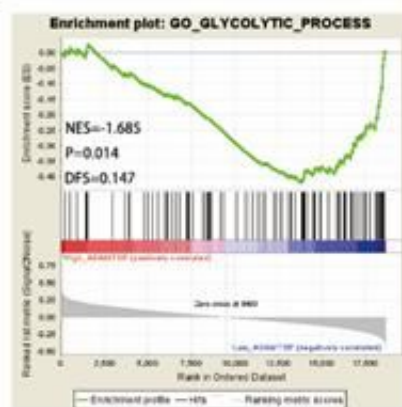

$\mathrm{H}$

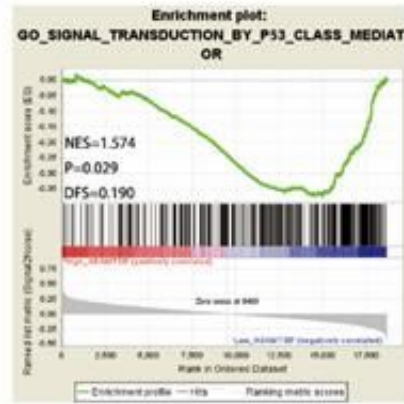

C

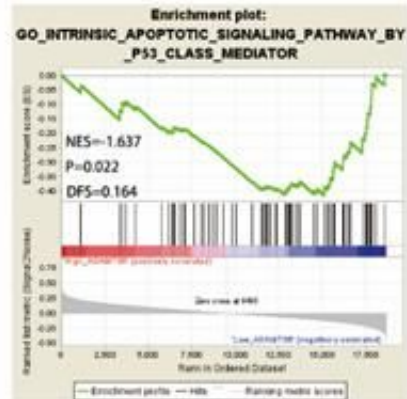

$\mathrm{F}$

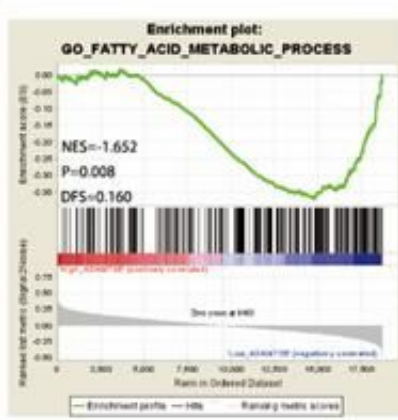

I

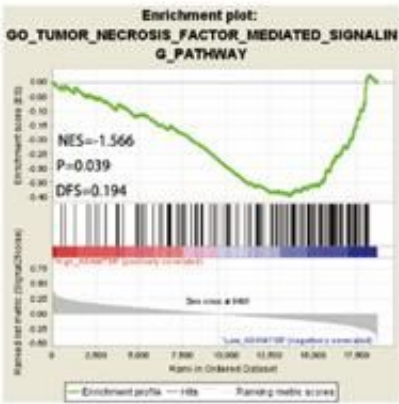

Figure 14

Gene set enrichment analysis (GSEA) of C5 gene sets for low ADAMTS6 expression groups. 